\title{
Tradition and Culture in Africa: Practices that Facilitate Trafficking of Women and Children
}

Norah Hashim Msuya

Mzumbe University, noranewtz@yahoo.com

Follow this and additional works at: https://digitalcommons.uri.edu/dignity

Part of the Civil Law Commons, Civil Rights and Discrimination Commons, Common Law Commons, Criminal Law Commons, Criminal Procedure Commons, Criminology and Criminal Justice Commons, Family Law Commons, Family, Life Course, and Society Commons, Gender and Sexuality Commons, Health Law and Policy Commons, Human Rights Law Commons, Inequality and Stratification Commons, Law and Gender Commons, Legal Theory Commons, Legislation Commons, Politics and Social Change Commons, Rural Sociology Commons, Sexuality and the Law Commons, and the Social Control, Law, Crime, and Deviance Commons

\section{Recommended Citation}

Msuya, Norah Hashim (2017) "Tradition and Culture in Africa: Practices that Facilitate Trafficking of Women and Children," Dignity: A Journal of Analysis of Exploitation and Violence: Vol. 2: Iss. 1, Article 3. https://doi.org/10.23860/dignity.2017.02.01.03

This Review Article is brought to you for free and open access by DigitalCommons@URI. It has been accepted for inclusion in Dignity: A Journal of Analysis of Exploitation and Violence by an authorized editor of DigitalCommons@URI. For more information, please contact digitalcommons-group@uri.edu. 


\title{
Tradition and Culture in Africa: Practices that Facilitate Trafficking of Women and Children
}

\begin{abstract}
Many states in Africa have adopted legislative, administrative and institutional measures to combat trafficking in human beings. These measures include, among other things, the formulation and implementation of both national and regional action plans by African states to provide for comprehensive and coordinated interventions. Many African countries have also enacted an anti-trafficking legislation at the country level. Despite these measures, African women and children have been trafficked annually worldwide for purposes of forced labor, sexual exploitation, and domestic servitude. Additionally, women and children are trafficked within their countries from rural to urban areas. Misconception and abuse of African tradition and culture have been one of the underlying root causes of human trafficking. Cultural practices, such as forcing young girls into ritual servitude, Trokosi (slaves to the Gods), Wahaya (fifth wife), Ukuthwala (kidnapping girls for marriage), payments of dowry, male dominance, female genital cutting, witchcraft, and child marriage, perpetuate the crime of human trafficking. Some women and young girls in Africa, many of whom migrate from rural to urban areas, find themselves compelled by these cultural beliefs to leave their home and family. This crime has been taking place imperceptibly for a long time. More often than not, incidents have been reported, and charges such as statutory rape and kidnapping are filed against the perpetrators, without authorities knowing that they constitute the offense of trafficking. Although most African traditions and cultural practices are positive when they are distorted and abused, they perpetuate serious problems like trafficking.
\end{abstract}

\section{Keywords}

Trokosi, slaves to the Gods, Wahaya, fifth wife, Ukuthwala, kidnapping girls for marriage, witchcraft, female genital mutilation, child marriage, dowry, gender inequality, male dominance, son preference

\section{Creative Commons License}

\section{c) (i) $\ominus$}

This work is licensed under a Creative Commons Attribution-Noncommercial-No Derivative Works 4.0 License.

\section{Acknowledgements}

With the permission of the reviewers and the author, Dignity thanks the following reviewers for their time and expertise: Esohe Aghatise, executive director of Associazione Iroko Onlus and Visiting Lecturer, United Nations Interregional Crime and Justice Research Institute (UNICRI) and University of Turin Department of Law, Italy, and Despina Learmonth, PhD, University of Cape Town, South Africa. 


\section{DIGNITY}

Volume 2, Issue 1, Article 3, 2017
A JOURNAL ON

SEXUAL EXPLOITATION

AND VIOLENCE

\title{
TRADITION AND CULTURE IN AFRICA: PRACTICES THAT FACILITATE TRAFFICKING OF WOMEN AND CHILDREN
}

\author{
Norah Hashim Msuya \\ Mzumbe University
}

\begin{abstract}
Many states in Africa have adopted legislative, administrative and institutional measures to combat trafficking in human beings. These measures include, among other things, the formulation and implementation of both national and regional action plans by African states to provide for comprehensive and coordinated interventions. Many African countries have also enacted an anti-trafficking legislation at the country level. Despite these measures, African women and children have been trafficked annually worldwide for purposes of forced labor, sexual exploitation, and domestic servitude. Additionally, women and children are trafficked within their countries from rural to urban areas. Misconception and abuse of African tradition and culture have been one of the underlying root causes of human trafficking. Cultural practices, such as forcing young girls into ritual servitude, Trokosi (slaves to the Gods), Wahaya (fifth wife), Ukuthwala (kidnapping girls for marriage), payments of dowry, male dominance, female genital cutting, witchcraft, and child marriage, perpetuate the crime of human trafficking. Some women and young girls in Africa, many of whom migrate from rural to urban areas, find themselves compelled by these cultural beliefs to leave their home and family. This crime has been taking place imperceptibly for a long time. More often than not, incidents have been reported, and charges such as statutory rape and kidnapping are filed against the perpetrators, without authorities knowing that they constitute the offense of trafficking. Although most African traditions and cultural practices are positive when they are distorted and abused, they perpetuate serious problems like trafficking.
\end{abstract}

\section{KEYWORDS}

Trokosi, slaves of God, Wahaya, fifth wife, Ukuthwala, kidnapping girls for marriage, witchcraft, female genital mutilation, child marriage, dowry, gender inequality, male dominance, son preference

$\mathrm{M}$

UCH HAS BEEN WRITTEN about women's human rights and the harmful gender-related cultural practices that affect them, particularly in Africa but also elsewhere. Although the focus in scholarly investigations has mainly been on the link between harmful cultural practices and the violation of women's rights, research that has explored the link between such practices and human trafficking is limited. Thus, the purpose of this article is to highlight and discuss harmful African cultural practices that contribute to human trafficking and the sexual slavery of women in Africa, with a particular focus on the human rights violations that arise from these practices. The purpose and methodology of this research are underpinned by the author's experience and knowledge accumulated 
during her career, and an analysis of published academic literature, as well as relevant international, regional, and domestic instruments.

African countries have joined global efforts to combat human trafficking since 1981 by ratifying the African Charter on Human and Peoples' Rights (ACHPR) instruments. This Charter prohibits slavery and human trafficking (Thipanyane, 2015). Also, the African Union adopted two instruments that have specific provisions on the protection of women and children against slavery. These are the African Charter on the Rights and Welfare of the Child of 1990 (ACRWC) and the Protocol to the African Charter on Human and People's Rights on the Rights of Women in Africa of 2003, also known as the Maputo Protocol (Ruby \& Benjamin, 2012). The African Union also adopted the Ouagadougou Action Plan to Combat Trafficking in Human Beings, Especially Women and Children, in 2006. These instruments reconfirm international treaties on human trafficking and thus encourage African states to adopt legislative, administrative and institutional measures to combat trafficking in human beings. The Ouagadougou Action Plan encourages the formulation and implementation of both national and regional action plans by African states toward achieving comprehensive and coordinated interventions.

In addition to the adoption of these instruments, there are also sub-regional efforts to combat human trafficking, which occurs in Africa. These include, among others, the Southern African Development Community (SADC) Regional Plan of Action on Trafficking in Persons (2009-2019), the joint ECOWAS/ECCAS Regional Plan of Action to Combat Trafficking in Persons, especially Women and Children (2006-2009), and the Economic Organization of West African States (ECOWAS) Initial Plan of Action against Trafficking in Persons (2002-2003). At the state level, many African countries have enacted anti-trafficking legislation to incorporate international instruments (Ruby \& Benjamin, 2010). Additionally, many African countries have established dedicated anti-trafficking agencies, such as the National Agency for Prohibition of Traffic in Persons and Other Related Matters (NAPTIP) of Nigeria (UNODC, 2012). However, notwithstanding these international, national, and regional measures to combat human trafficking, levels of human trafficking remain high in many African countries (Thipanyane, 2015). Thousands of African women and children are annually trafficked from West Africa to Western Europe to be subjected to forced commercial sex work (UNDOC, 2014). Nigeria, in particular, is reported to be the largest single source of trafficked women in Europe and the Middle East (Thipanyane, 2015). The 2014 Global Slavery Index shows that South Africa is estimated to have 106,000 victims of modern slavery, while Nigeria and the Democratic Republic of Congo have an estimated 834,200 and 762,900 similar victims respectively (Thipanyane, 2015). There is also widespread evidence of internal trafficking for domestic work in East African countries (IOM, 2008).

The United Nations (UN) Protocol to Prevent Trafficking in Persons adopted in 2000 defines trafficking in persons as follows:

[It is] the recruitment, transportation, transfer, harbouring or receipt of persons, by means of the threat or use of force or other forms of coercion, of abduction, of fraud, of deception, of the abuse of power or of a position of vulnerability or of the giving or receiving of payments or benefits to achieve the consent of a person having control over another person, for the purpose of exploitation. Exploitation shall include, at a minimum, the exploitation of the prostitution of others or other forms of sexual 
exploitation, forced labor or services, slavery or practices similar to slavery, servitude or the removal of organs (The UN Protocol to Prevent, Suppress, and Punish Trafficking in Persons, Especially Women and Children of 2000, Article 3a).

The definition is meant to provide consistency and consensus around the world on the phenomenon of trafficking in persons. The Protocol also provides that the consent of a victim of trafficking in persons for intended exploitation is irrelevant once deception, coercion, force, or other prohibited means have been used (Article $3 \mathrm{~b}$ ). Therefore, consent cannot be used as a defense to absolve traffickers from criminal responsibility. The Protocol further states that in trafficking cases involving children, "the recruitment, transfer, transportation, harboring or receipt of a child for the purpose of exploitation shall be considered trafficking in persons, even if this does not involve any improper means such as coercion, deception, etc." (Article 3c). This means that the Protocol acknowledges that a child, who is a person under the age of 18, cannot give valid consent in any circumstance. The Protocol requires that any conduct as set out in Article 3 be criminalized in domestic legislation (Article 5). The enabling and contributing factors involved in human trafficking that have been identified include, among others, poverty, unemployment, internal and external conflict, lack of access to education, porous borders, poor law enforcement, cultural misconceptions or abuse, regional conflict, and HIV/Aids (Ruby \& Benjamin). It is notable, however, that new international standards define human trafficking in terms of how the victim is exploited and in terms of the victim being in transit (Harrop, 2012). Thus, while a person may be trafficked overseas and across borders, a trafficked person may also be one who is exploited in his or her current location. Three major types of trafficking in persons have been identified in Africa. These are: trafficking in women and young persons for sexual exploitation, mainly outside the region; trafficking in children primarily for farm labor and domestic work within and across countries; and trafficking in women from outside the region for the sex industry (Adepoju, 2005).

\section{African Cultures that Fuel Trafficking in Women and Children}

It bears repeating that trafficking takes place at different levels within, outside, among, and into countries for reasons of exploitative labor, domestic work, and sexual exploitation of women and young children. Misconception and abuse of African cultures are among several factors that contribute to trafficking in Africa (Thipanyane, 2015). Culture is socially constructed and as such, it does not exist independently of the people who construct it. Arguably, people create and define their culture based on society's needs. It is thus notable that where they live, they need to understand the world not only in terms of what defines their society, but also what ensures their survival, prosperity, and progress (Richard, Stephen, \& Steinner, 2010). All African communities have certain practices that reflect their values and beliefs. These practices reflect both positive and negative aspects of the traditional culture of those communities. The positive aspects are always beneficial to all the members of those communities. Africans have many positive cultural values such as solidarity, tolerance, respect for elders, caring for the needy, sharing, negotiating, discussing, and even mediating (Idang, 2015). However, there are also traditional practices in Africa that are harmful to certain groups in the communities, such as women and children. It is widely acknowledged that in nearly every country in Africa, women are subjected to second-class citizen status. They are earning significantly less than their male counterparts and are further subjected to 
inequalities that far exceed pay gaps (White, 2013). There has been a growing connection between human trafficking and certain harmful cultural beliefs and practices, particularly because traditional practices that devaluate women and girls in society make them disproportionately vulnerable to trafficking (UNODC, 2013). Moreover, women's access to and control of economic resources, as well as their access to education, are severely limited by such practices. When women and young girls are exposed to violence, abuse, and exploitation, they become vulnerable to being trafficked (UNODC, 2012). Some African traditions and cultural practices that contribute to human trafficking and violation of human rights are discussed below.

\section{Trokosi: Slave to the Gods}

Trokosi, or "slave to the gods," is a traditional practice that is widespread in West African countries such as Ghana, Benin, Togo, and south-western Nigeria (Aird, 2001). This tradition involves young virgin girls from the Ewe ethnic group who are sent to live as forced laborers in traditional shrines. Apart from being used as slave laborers, these young girls are also used as sex slaves by the priests residing in the shrines. According to this religious custom, when a relative commits a crime, ranging in severity from petty theft to murder, the family must offer a virgin daughter, typically from six to 15 years of age, to the local shrine where she will become a trokosi, or "slave to the gods" (Aird, 2001). Once a girl has been sent into trokosi servitude, she becomes a trokosi for the rest of her life, and if she dies, she has to be replaced by her family (Parrot \& Cumming, 2006). The trokosi has a duty to serve the priests domestically, satisfy their sexual desires, and work on their farms to provide for their economic security (Parrot \& Cumming). In this sense, the priest then exerts full ownership rights over the girl, which gives him the right to beat her when she tries to escape, control her interaction with others, and demand labor and sex from her. Her deprivation extends to being denied education, food, and basic health services (Zimmerman, 2002). The brutal conditions under which shrine priests keep trokosi slaves meet the definition of trafficking in persons as provided by both the UN international and several African regional instruments such as Article 3 of UN Convention against Transnational Organized Crime and its two related protocols: the United Nations Protocol to Prevent, Suppress, and Punish Trafficking in Persons, Especially Women and Children; and the United Nations Convention against Transnational Organized Crime, Articles $8(1)$ and $8(2)$ of the ICCPR.

It bears repeating, therefore, that families willingly sacrifice a virgin daughter to a shrine in exchange for "the gods' forgiveness." To this end, they deliver their child to the priest for sexual and economic exploitation, which is a practice that clearly falls under the extended definition of human trafficking (Parrot \& Cumming). Parents believe that they will suffer disease, misfortune, or even a succession of deaths if they do not appease the gods by sacrificing a virgin (Aird, 2001). On occasion, they also send virgin daughters to acquire good luck and better fortune. (Aird, 2001). According to various estimates, there are over 5,000 trokosi slaves in Ghana alone, and in the other four countries where the practice continues, there are as many as 29,000 to 35,000 such slave girls (Asomah, 2015). Generally, priests do not see visitors unless they bring an offering. Shrine owners, to whom the priests are accountable, are elderly members of the clan or family who own the fetish shrine, and like the priests, they reap economic benefits from trokosi slavery (Asomah, 2015). For both groups, trokosi slaves are a very welcome windfall. 
Priests often force slaves to work more than 12 hours a day, often in the hot sun and do not compensate them for their work (Otnes \& Tuncay-Zayer, 2012). Slaves must hand over to the priest the greatest share of any earnings they collect from farming and petty trading. Sometimes the priest provides no financial support whatsoever to his slaves, making them dependent upon their families for food and clothing (Parrot \& Cumming, 2006). Sadly, many families are afraid to visit their daughter at the shrines or do not have the resources to provide food and clothing, leaving many shrine slaves in a state of perpetual malnourishment or semi-starvation (Parrot \& Cumming, 2006). Furthermore, priests prohibit all slaves from attending school and deny them access to any form of health care.

The practice of trokosi was banned in West African countries after an international outcry from human rights activists. In Ghana, where trokosi was mostly practiced by the Ewe tribe, it was banned in 1998. Nonetheless, more than 15 years after trokosi servitude was abolished, an estimated 3,000 to 5,000 trokosi remain enslaved in Ghana today (Thipanyane, 2015). Activists have had to address the economic concerns of priests and shrine owners, as well as appeal to their sense of morality (Thipanyane, 2015). In exchange for the release of trokosi slaves, shrines often request cash, cattle, and alcohol. Activists hope that these incentives will replace the economic benefits derived from having trokosi slaves, leaving shrines self-sufficient (Lillie, 2013). One of the international organizations called International Need encourages shrine owners and priests to participate in the negotiation process by giving them money, such as $\$ 74$ (US), and if the shrine owners and priests agree to release the trokosi women and girls, International Needs in Ghana gives them up to $\$ 925$ to use for the liberation ceremony (Namazie, 2001). However, some activists are concerned about the offering of cash and other material incentives in exchange for the liberation of trokosi slaves, as this has the potential of encouraging priests and shrine owners to try to acquire more slaves in the hope of reaching profitable settlements (Namazie, 2001). During the liberation ceremony, the priests and shrine owners sign legal documents acknowledging that the trokosi slaves and their families are henceforth free from all obligations to the shrine (UNHROHC, 2012). This kind of liberation practice essentially cements the elements of human trafficking, which is something that law enforcers are supposed to bring to an end instead of allowing the activists to keep on offering money to the criminals of severe human trafficking, as in the case with the trokosi practice.

The trokosi culture is against many international human rights laws, including the United Nations Human Rights Declaration, which was adopted and proclaimed as a common standard for all peoples and all nations of the rights found therein. This Declaration proclaims that "all human beings are born free and equal in dignity and rights" (Universal Declaration of 1948, Article 1). Article 2 of this declaration establishes that:

"Everyone is entitled to all the rights and freedoms set forth in this Declaration, without distinction of any kind, such as race, color, sex, language, religion, political or other opinion, national or social origin, property, birth or other status" and that "everyone has the right to life, liberty and security of person."

Article 3 further provides that "no one shall be subjected to torture or cruel, inhuman or degrading treatment or punishment." Trokosi culture violates this Universal Declaration because girls taken to the shrines are stripped of their liberty, security of person, and dignity, and they are subjected to cruel, inhuman, 
and degrading treatment by being enslaved to other human beings against their will, having to work under the complete control of the priests and having to satisfy the priests' sexual desires. Rape and abuse of these girls may be considered violations of Articles 3 and 5 of the Universal Declaration. Likewise, their treatment amounts to the definition of torture found in the Convention against Torture and other Cruel, Inhuman or Degrading Treatment or Punishment (Article 1 of the Convention against Torture and other Cruel, Inhuman or Degrading Treatment or Punishment of 1984). Together, these articles prevent the violation of a person's bodily integrity and sexuality by means of any form of degrading or cruel acts. The African Charter on the Rights and Welfare of the Child, which Ghana and all West African states ratified, requires all member states to eliminate customs and practices that are detrimental to children (Article 16). In particular, Article 21 calls for member states to abolish "those customs and practices prejudicial to the health or life of the child, and those customs and practices discriminatory to the child on the grounds of sex or other status."

The Preamble of the African Charter on the Rights and Welfare of the Child recognizes the importance of human rights and states that special safeguards and care are needed for African children due to unique factors of socio-economic, cultural, traditional and developmental circumstances, natural disasters, armed conflicts, exploitation, and hunger. The trokosi culture violates the Charter because it subjects children to degrading treatment and sexual abuse. Additionally, as a cultural practice, it is harmful to the welfare, dignity, and normal growth and development of the girls enslaved to the priests. This practice also violates the Convention to Suppress the Slave Trade and Slavery as well as the Supplementary Convention on the Abolition of Slavery, the Slave Trade, and Institutions and Practices Similar to Slavery of 1926 . This Convention is defined as the status or condition of a person over whom any or all of the powers attaching to the right of ownership are exercised (Article 1). This Convention further requires State members to adopt all appropriate measures to prevent, suppress, and abolish slavery in all of its forms, including compulsory and forced labor (Article 2).

Ghana and most African countries have ratified the Convention to Suppress Slavery of 1926, which was adopted by the UN to allow states to continue the efforts begun by the League of Nations in abolishing slavery, as well as the 1956 UN Supplementary Convention on the Abolition of Slavery, the Slave Trade, and Institutions and Practices Similar to Slavery (United Nations, Human Rights: International Instruments, Chart of Ratifications 5, 1995). The Convention to Abolish Slavery also requires states to take all measures to "abolish debt bondage, serfdom, forced marriage, and any practices whereby a child or young person under the age of 18 years is delivered by either or both of his natural parents or by his guardian to another person, whether for reward or not, with a view to the exploitation of the child or young person or of his labor" (Article 1). Trokosi culture violates the Convention to abolish slavery because it is slavery, and it involves serfdom as well as the exploitation of children and their labor. Other states that are party to the Convention to abolish slavery are supposed to refer Ghana to the International Court of Justice to resolve the conflict between the application of this Convention and the existence of trokosi, as required by Article 10 of the Convention. Unfortunately, this has not occurred, and history has shown that states have been reluctant to intervene (Levesque, 1994).

Another international human rights instrument that is directly violated by trokosi culture is the International Covenant on Civil and Political Rights (ICCPR), 
which also requires that states that are party to it protect their citizens against slavery and cruel, inhuman, or degrading treatment, and to recognize their rights to life, liberty, security, and privacy. However, although freedom from torture is explicitly granted in the ICCPR, it leaves torture undefined and provides no criteria to distinguish between torture and acts of cruel or degrading treatment. The trokosi culture violates the ICCPR as its practices are torturous, cruel and degrading treatment because the girls are under the complete control of the priests. The trokosi girls are forced to work long hours in the fields of the shrine, without pay, and are forced to provide sexual favors to the priest and bear children to him. Additionally, trokosi violates the ICCPR because it is slavery and degrading treatment, and discriminates based on sex. Moreover, it violates the liberty, security, and privacy of the enslaved girls and women. Ghana has also ratified the ICCPR and is thus subject to its enforcement mechanisms for noncompliance.

Other international instruments that Ghana and other West African countries have ratified and that are thus violated by the trokosi culture include the United Nations Convention on the Rights of the Child of 1989, the International Covenant on Economic, Social and Cultural Rights of 1966 (Articles 3, 6, 7, 10(3), and 13), the Convention on the Elimination of All Forms of Discrimination Against Women (CEDAW) of 1979 (Articles 2, 3, 8 and 10), the Protocol to the African Charter on Human and Peoples' Rights on the Rights of Women in Africa of 2003, and the African Charter on Human and Peoples' Rights of 1981 (Articles 2, 3, 4, 5, 6, 12, 15 , 18, and 19). The 1992 Constitution of Ghana, under Articles 16(1) and 16(2), stipulates that no person shall be held as a slave or be subject to servitude. Further, Article 26(2) of this Constitution criminalizes any customary practice that dehumanizes or endangers the physical and mental well-being of any citizen. Accordingly, the trokosi practice violates the constitutional provisions that prohibit any form of slavery. The Ghanaian Constitution also defines the fundamental human rights and freedoms that are to be respected and upheld by the government and individuals under Article 12(1) and that are applicable to every person in Ghana, regardless of race, place of origin, political opinion, color, religion, creed, or gender (Article 15(1)). Article 26(1) of the Ghanaian Constitution provides for cultural rights, with the exception under Article 26(2) where they dehumanize or are injurious to the physical and mental well-being of a person, such as the trokosi culture does. Article 28(3) and (4) of Ghana specifically provides for child protection:

Every child has the right to be protected from engaging in work that constitutes a threat to his health, education or development, and a child shall not be subjected to torture or other cruel, inhuman or degrading treatment or punishment.

The trokosi culture violates children's rights conferred upon them by this Constitution as it tears girls from their families, denies them access to education, denies them payment for their work, and denies the shrine's support for the children they bear to the priests. Because the girls are left under the complete control of the shrine priests, they are often sexually abused and exploited for their labor, which exposes them to moral and physical hazards. The law of Ghana encompasses elements of common law, the doctrine of equity, and the rules of customary law (Levesque, 1994). Customary law refers to the rules of law that, by custom, are applicable to particular communities in Ghana. The Constitution explicitly criminalizes slavery under Article 16(1) and (2), which is violated by the trokosi culture. The country has also enacted the Ghana Human Trafficking Act 694 in 2005 
(http://www.parliament.gh/library.php?id=37). This law prohibits human trafficking (Section 2), provision of trafficked persons (Section 3), use of trafficked persons (section 4), and conveyance in trafficking. Section 314 of the Ghanaian Criminal Code criminalizes slavery, stipulating that offenders of this law are guilty of a second-degree felony. Nevertheless, the trokosi practices are usually coerced by family members, especially parents, who questioned whether that criminal code section covered this particular customary practice (Namazie, 2001). Thus it was argued that the 'coercion' referred to under Section 314 would not apply, as parental 'coercion' was lawfully exercised by virtue of contracts of service between free persons (i.e., the parents and a priest), or by virtue of the rights of parents and other rights, not being contrary to law, arising out of family relations customarily used and observed in Ghana (Namazie, 2001). However, after lobbying by nongovernmental organizations, the government of Ghana amended a section of its Criminal Code in 1998 and criminalized all forms of "customary or ritual servitude," including the trokosi system (Ameh, 2004).

Sadly, this practice persists because of deeply entrenched traditional beliefs, and it is, therefore, unlikely that any legislative prohibition alone will eliminate the practice (Ayton-Shenker, 1995). Beliefs in traditional rituals and the spirit world permeate the highest levels of most West African societies, making it difficult to convince traditional believers to give up time-honored cultural practices. Moreover, the varying accounts or estimates of the trokosi phenomenon reveal inconsistencies and conflicting reports that do not illuminate the truth about this continued practice and the human rights violations it engenders. The fact that this practice continues despite the enactment of the law that prohibits the trokosi practice in Ghana is a grave concern, as was noted recently by the African Children's Committee (ACCRC, 2015). This means that innocent virgin girls may still be subject to this practice should any member of their families commit a crime that warrants such a sacrifice to the gods. Moreover, the plight of the children born to these girls perpetuates the violation of basic human rights, and particularly children's rights, in its severest form. For these reasons, there is a need for continued, coordinated interventions to eradicate this practice.

\section{Wahaya: The Fifth Wife}

The Wahaya culture is practiced mostly in Niger, which is situated in West Africa. Niger is a predominantly Muslim country that allows polygamy because the Qur'an permits a Muslim man to have up to four wives, as long as he treats them equally (Lillie). Each wife after the first four is considered to be a Wahaya, or 'fifth wife' (Asomah, 2015). The fifth wife is the unofficial wife who acts as a slave to the first four wives and the husband (Asomah, 2015). These Wahaya are often young girls, usually between the ages of nine and 14, who are enslaved when their parents are sold into slavery (Lillie, 2013). In 2012, Anti-Slavery International interviewed 10 Wahaya in Niger and heard their testimonies of frequent abuse and rape by their husbands and the terrible living conditions and daily chores they are subjected to by the legal wives (Banda, 2005). Usually, they are in charge of watching the children, cooking, cleaning, and taking care of the livestock. Rich men who live in large compounds with their four legal wives are the ones who allegedly buy up to 10 Wahaya. For the men, having the Wahaya is a sign of prestige and, as a result, many men have more than one. Children born to a Wahaya are considered legitimate, and this causes concern for the legal wives whose children stand to inherit less, the more children the Wahaya have (Abdelkader \& Zangaou, 2012). This 
tradition requires the Wahaya to endure abuse from their husband and his legal wives for the rest of their lives. Moreover, their female children will most likely be sold by their husbands to live as Wahaya as well (Abdelkader \& Zangaou, 2012).

This culture of slavery is passed down from generation to generation, and it has become a kind of social class (Maki, 2013). Measuring the magnitude of this problem has been difficult because it is hidden. This fact notwithstanding, Anti-Slavery International's report estimates there are thousands of Wahaya, 83\% of whom have been sold when they were younger than 15 (Abdelkader \& Zangaou, 2012). It has also been reported that some businessmen simply sell their Wahaya to others when their business is failing, especially when the Wahaya have no children (Abdelkader \& Zangaou, 2012). From a religious perspective, some people believe that possession of a Wahaya is legitimized by a certain interpretation of verse 3 of Surah 4 of the Holy Qur'an, which reads:

... and if you fear that you cannot act equitably towards orphans, then marry such women as seem good to you, two and three and four, but if you fear that you will not do justice (between them), then (marry) only one or those your right hand possesses.

This cannot, however, be used to justify the present practice, in particular, because Wahayu are Muslim, and Islam states that a Muslim cannot enslave another Muslim (Abdelkader \& Zangaou, 2012). There is thus a clear paradox in this cultural practice, particularly when young girls who have been sold are violated and when repeated sexual abuse is considered normal. Moreover, certain women in this cultural practice are believed to have no soul, and certain children are treated as inferior to others. This is a world of endless work and cruelty, and many of these Wahayu attempt to flee in the hope of starting a new life. This practice also clashes with several provisions of UN international instruments that Niger has signed and ratified, including the International Labor Organization's Minimum Age Convention of 1973, the Palermo Protocol, which is a supplement to the UN Convention against Transnational Organized Crime (2000), the ILO Forced Labor Convention (Convention No. 29 of 1930), ILO Abolition of Forced Labor Convention (Convention No. 105 of 1957), the Slavery Convention (1926), the International Covenant on Civil and Political Rights (ICCPR), the Protocol to Prevent, Suppress, and Punish Trafficking in Persons, Especially Women and Children, supplementing the United Nations Convention against Transnational Organized Crime of 2000, as well as CEDAW and the CRC. The Wahaya practice as a form of human trafficking also violates numerous African regional instruments, including the ACHPR, the African Charter on the Rights and Welfare of the Child, and the Maputo Protocol. National and international civil organizations such as BAOBAB for Women's Human Rights, The International Dalit Solidarity Network, Transparency International (TI) and Anti-Slavery International have repeatedly held the Niger government accountable, urging it to comply with the international conventions it has ratified (Maki, 2013).

Moreover, the Wahayu culture is clearly a travesty of the anti-trafficking law of Niger. According to Order No. 2012-86 of the Combating Trafficking in Persons Act promulgated in 2010, all forms of trafficking, including slavery and practices similar to slavery, are prohibited. Section 3 of the law prescribes sufficiently severe punishments of five to 10 years' imprisonment for committing trafficking offenses against adults and 10 to 30 years' imprisonment when the offense has been 
committed against a child. Penalties for child trafficking in this legislation are commensurate with those prescribed for other serious offenses such as rape, but those prescribed for trafficking of adults are not. The Act defines slavery and practices similar to slavery and specifically prohibits exploitative begging under section 2 . The 2010 Act led to the creation of the National Coordination Commission and the National Agency for Combating Human Trafficking in 2012. Another statute that prohibits certain forms of trafficking in Niger is the Penal Code, which was amended in 2003 to prohibit slavery, procurement of a child for prostitution, and the encouragement of or profiting from child begging (Articles 270, 292-293, and 181). Niger's Labor Code, which was enacted in September 2012, also outlaws forced labor under Article 2.

The Niger government adopted the National Action Plan for the Fight against Trafficking in Persons and allocated resources to fund the National Commission for the Coordination of the Fight against Trafficking in Persons (CNCLTP), which is currently serving as the coordinating body for anti-trafficking efforts and its implementing agency, the National Agency for the Fight against Trafficking in Persons (ANLTP) (US Department of State, 2015). Although the Niger government has continued to identify and refer victims to NGOs to receive care, the authorities have recently identified fewer victims, and the overall availability of protective services to victims seems inadequate (US Department of State, 2015). In May 2014, the Niger government cooperated with international partners to train 30 police chiefs and magistrates from across the country on effective application of the 2010 trafficking law in Niamey. The government conducted similar training programs in other Niger townships namely Agadez, Arlit, and Zinder. Unlike the previous year, there were no investigations, prosecutions, or convictions of government officials for complicity in trafficking or trafficking-related criminal activities. The United States Department of Labor's 2013 Trafficking in Persons report shows that, in the preceding year, the Niger government had made progress in enforcing its 2010 Law on Combatting Trafficking in Persons, but efforts to identify victims such as Wahaya in vulnerable populations remained weak. Since then, the Niger government has taken significant steps toward eradicating slavery and slavery-like practices, but many challenges remain, as the United Nations Special Rapporteur, Urmila Bhoola, observed recently:

The criminalisation of slavery and the adoption of legislation penalising contemporary forms of slavery is [sic] an indication of the government's commitment to comply with its international human rights obligations; however, the limited number of prosecutions indicates that stronger law enforcement is necessary and that resource and capacity constraints still exist" (Niamey, 2014).

A landmark decision on Wahaya practice occurred in the case of Maniv. Niger in the Community Court of Justice of the Economic Community of West African States (ECOWAS) on 7 October 27, 2008. The case served as the first regional court decision to be heard on the issue of slavery in Africa and set a regional standard in international human rights law (Beirnauer, 2009). The facts of the case were well reported, and are the following: Hadijatou Mani Koraou, who was 12 years old in 1996 and had been born into slavery in a Tuareg community, was sold for $\$ 400$ (US) to 46-year-old El Hadj Souleymane Naroua as his fifth wife under the Wahaya custom. Mani gave birth to four children to Naroua when staying under his slavery for more than nine years of violence and a forced sexual relationship. 
In 2005, Naroua formally freed Mani by signing a formal document of agreement. However, he later declared that she was his wife and prevented her from leaving his house. In 2006, Mani went to court and received an initial judgment. The Nigerian Civil Court freed her from the marriage because the court declared, there had never been a religious ceremony that officiated the marriage. The ruling was then reversed at the Tribunal de Grand Instance (TGI) which based its judgment on customary law. Mani appealed to the Supreme Court, and the Supreme Court sent the case back to be determined by the TGI. Pending the determination of the case (Jean, 2009), Mani married a husband of her own choice and Naroua responded by filing a criminal complaint and getting Mani and her new husband convicted of bigamy and sentenced to six months in prison. It was the judgment of this court that Mani was still legally married to Naroua and used her slave status as a justification for the marriage. Mani appealed to the Court of Appeal of Niamey, which decided to await the ruling of the newly assembled TGI and to align with that. Mani filed charges against Naroua for slavery in response to the charge of bigamy, and followed this with a petition to the ECOWAS court on December 14, 2007, asking them to find the state of Niger in violation of articles 1, 2, 3, 5, 6 and 18(3) of the African Charter on human and peoples' rights.

In the ECOWAS court, Niger argued that the case was inadmissible to that court because domestic remedies had not been exhausted. They also argued that although slavery still existed in Niger, they had made gains against it and it was largely being limited. The ECOWAS court ruled that neither argument was sufficient and decided in favor of Mani. The court rejected the issue of domestic exhaustion and used the precedent of the Barcelona Traction International Court of Justice case and provided that slavery required special attention by all organs of the state. The court also said that Mani had clearly been a slave and that the State of Niger had been responsible for not doing enough to protect her as a citizen against slavery. The court awarded Mani $\$ 21,500$ (US) in damages. The court interpreted the term of slavery in the modern context and highlighted the use of powers associated with ownership and elements of control over a person. It concluded that Mani's case constituted slavery beyond any doubt and that Mani had been abused in slavery conditions for nearly a decade. The judgment offers hope for tens of thousands of slaves in Niger -- research has indicated that there are at least 43,000 slaves in Niger and that tens of thousands are still held in servitude in the region as a whole (Beirnauer, 2009). The case suggests that legal redress is no longer unrealistic and encourages others to take cases to court or to have cases brought forward by trade unions and other anti-slavery organizations. Relevant stakeholders also need to disseminate the strong message sent out by this regional African court, not in the least to judges in the national courts of the region.

\section{Ukuthwala: Kidnapping Girls for Marriage}

Ukuthwala is a traditional custom of kidnapping girls for marriage, which is still a popular practice in Southern Africa (DJCDGD, 2010). This traditional practice involves a man and his friends or peers who set out to compel a girl or young woman's family to endorse marriage negotiations (Van Schalkwyk, 2000). Also, a girl may be abducted by a man while she is walking down the road, then taken somewhere else where she is raped. Then the man asks the girl's family for her hand in marriage. Because rape still carries a stigma, the girl's rape renders the family vulnerable and susceptible to agreeing to the proposed marriage, as they do not have any other option (Van Schalkwyk, 2000). Ukuthwala is practiced mainly 
by men of the Xhosa tribe in some of South Africa's most rural and poor areas, such as in KwaZulu-Natal and in the Eastern Cape (DJCDGD). A similar tradition is also popular in Tanzania among the Chagga and Nyamwezi tribes (Wambura \& Khaday, 2010). Girls as young as 12 years old are grabbed kicking and screaming from the street and taken away to the homestead of their admirers (Wambura \& Khaday, 2010). The abducted girls are apparently given potions or a brew to make them pliable, and they are then forced to sleep with the abductor (DJCDGD, 2010). A girl who was kidnapped and raped cannot go back to her parents and cannot protest marriage to her captor because she is stigmatized. She will not be able to get married to another person, as no one will accept her. Hence the girls cannot get married to suitors of their own choice, but to suitors who are chosen by her parents. Sometimes they are simply married to their captors as 'fallen heroines' (Wambura \& Khaday, 2010).

After an abduction, the abductor sends a delegation to the abducted girl's home a day or two later to offer compensation to the victim's family (Mwambene, 2011). Some families accept the compensation as a dowry to marry their daughter off to the older man. However, many families nowadays fight back by refusing to accept the compensation and they further opt to press charges of abduction and rape against the perpetrators (Mwambene, 2011). In this cultural practice, girls are abducted for an illegal act, which turns them into sex slaves. (Hamman, 2014). It is notable that although the practice of ukuthwala has its roots in cultural tradition, it no longer functions within the parameters of its original purpose. Instead, it is being used to legitimize acts that are at their very core an abuse of these children's rights (Mwambene, 2011). This cultural practice goes back to the days when girls whose parents did not approve of their boyfriends arranged for the abduction so that the families would be forced to allow their marriage (Commission for the Promotion and Protection of the Rights of Cultural, Religious and Linguistic Communities, 2010). This was done to ensure that parents would be forced not only to accept the relationship, but also the dowry from the unwanted boyfriend, and the girl would then marry the man of her dreams after having given consent in this regard (Wambura \& Khaday, 2010).

Traditions and cultural practices were created by people in the past who applied them for a reason and out of necessity. Cultural practices are an important aspect of any given society and should be valued, understood, and passed on. However, when children and women are being abused, violated, forced into marriage, and trafficked in the name of and under the guise of "culture," society does need to re-evaluate its values about these practices. Committing an act of abduction or rape without the girl's consent is tantamount to her being subjected to forced marriage, which is illegal. Forced marriage also falls under exploitation in the definition of human trafficking as it is entrenched in international law, and in accordance with the parameters for human trafficking set out by the UN (Hamman, 2014).

South Africa has been in the forefront among the African countries in ratifying and implementing international and regional human rights institutions (Hamman, 2014). Thus, the Ukuthwala cultural practice is a violation of many UN and African regional human rights instruments. This practice also violates several legislative instruments in South Africa, including the Constitution of the Republic of South Africa, which enshrines the rights of all its citizens and affirms the democratic values of human dignity, equality, and freedom under its Sections 1(c), 2 and 7). Apart 
from violating Section 13 of the Constitution, which speaks against human trafficking, it also violates several other sections of the Constitution, including Sections 9 and 10, and Chapter 2 and 8 of the Promotion of Equality and Prevention of Unfair Discrimination Act, 2000 (PEPUDA). The PEPUDA Act deals with the prevention, prohibition, and elimination of unfair discrimination, hate speech and harassment on any of the prohibited grounds. Having sex with a child without her consent following her kidnapping and abduction constitutes rape and violation of Section 15 the Sexual Offences Act of South Africa.

This practice victimizes only girls; therefore it violates the Constitution's provision of gender equality (Sections 9 and 10). Girls are betrayed without their consent, which violates their bodily integrity and freedom, their right to personal security, their right to make choices, and, as children, their right to make decisions or to participate in decisions made about them. ${ }^{1}$ Further, the practice takes the form of a forced marriage and is no longer merely a preliminary process undertaken in the lead-up to a customary marriage, which is addressed in Section 211(3) of the Constitution. The practice of Ukuthwala involving a girl child is a crime in terms of the sexual exploitation of children and violence against children, as set out in Section 17 of the Sexual Offences Act of South Africa. This Act prohibits the sexual exploitation of children by their parents and others. Parents, relatives, or others who collude in, or aid and abet, the Ukuthwala of a girl child, commit the crime of sexual exploitation of children.

This culture leads to child marriages and therefore constitutes a serious legislative breach and a violation of children's rights. It violates South African Children Rights No 38 of 2005 under Section 17, which provides that a child, whether female or male, becomes an adult at the age of 18. However, Section 24(1) of the South African Marriages Act, No. 25 of 1961, allows marriage officers to solemnize a marriage between parties where one or both are minors upon consent of their parents. The South African Constitution clearly declares its supremacy, as it provides that any law or conduct inconsistent with it is invalid. The Constitutional Court has reiterated the supremacy of the principle of equality in the face of indigenous law that discriminated against women in several decisions such as in Gumede $v$ President of the Republic of South Africa (2009) and Bhe v The Magistrate of Khayelitsha (2005) Therefore, the Constitution renders all customary laws and practices that are in breach of constitutional provisions null and void.

The ukuthwala practice further violates the Children's Act, which prohibits "the use, procuring, or offering of a child for slavery or practices similar to slavery, including debt bondage, servitude, and serfdom, forced or compulsory labor or the provision of services, and for purposes of commercial sexual exploitation or trafficking" (Section 141). Sections 15 and 16 of the Criminal Law (Sexual Offences and Related Matters) Act of South Africa, criminalize the sexual exploitation of children. The custom also violates Sections 70 and 71 of the same Act, which specifically criminalize human trafficking of both adults and children for sexual exploitation and provide for services, including access to health facilities and free HIV/AIDS treatment. More often than not, what is happening to these girls is not referred to as trafficking, though some parents have reported this matter to the authorities (Hamman, 2014). Instead, charges such as assault, rape, and kidnapping are pressed against the offenders. However, categorizing ukuthwala under 
these crimes is not only inaccurate, but also undermines the severity of what has happened to the victim and, indeed, lets the perpetrator off the hook by not charging him with the actual crime that was committed. If parents and authorities are aware of the additional charge of trafficking that can be brought against such perpetrators, then justice may indeed prevail. The problem of not acknowledging trafficking when it occurs limits our own knowledge and awareness of the prevalence of the issue. If trafficking is not called trafficking, but rather something else referring to some of its parts such as illegal immigration, prostitution, bonded labor, child labor, or sexual exploitation, we will continue to miss opportunities to understand it to find solutions. There is also an urgent need to educate those who have a communication role, such as the media, journalists, NGOs, and government communication officers so that they send out a powerful message of the full extent of human trafficking and so that they will not continue to misreport it (Hamman).

\section{Witchcraft and Traditional Beliefs}

Traditional faith healing and witchcraft are among the cultural beliefs that infringe on the right of many to live free and fulfilling lives. The manner in which beliefs are distorted plays a role in promoting the abuse and exploitation of vulnerable children and women through human trafficking, and sometimes they also act as a barrier in preventing and prosecuting trafficking (Mesaki, 2010). Belief in witchcraft becomes negative when beliefs are misunderstood and distorted for personal gain (Mesaki, 2010). In such cases, the results can be devastating and can contribute to people perpetrating terrible acts of violence against unwitting victims that can lead to exploitation and/or death. These beliefs have led more often than not to intimidation, psychological isolation, abuse, violence and, in extreme cases, to the killing of older women simply because they have been accused of witchcraft whenever disaster happens in the community (HelpAge International Tanzania, 2008). Some of those suspected of witchcraft and members of their families have been burned to death in their homes in countries such as Tanzania (HelpAge International Tanzania, 2008).

People accused of practicing witchcraft have been punished by mob justice, which in many instances has led to the killing of the accused persons (Legal and Human Rights Centre, 2013). Older women seem to be the most affected members of the society (Legal and Human Rights Centre, 2013). For example, red eyes have been perceived to be a sign of one engaging in witchcraft practices. However, this can easily be explained because most elderly women in rural areas use firewood for cooking. The smoke causes their eyes to turn red, particularly if they have cooked over open fires for a long time (HelpAge International Tanzania, 2008). Gender bias associated with this phenomenon seems to be a symptom of the marginalization of women in society. Targeting women in witchcraft killing is also associated with ownership of property. Elderly women have been forced to leave their houses and villages and run away for fear of persecution. Elderly women who have immovable property, such as land and houses, have become vulnerable to attacks and killings with witchcraft used as an excuse to obtain their property (Legal and $\mathrm{Hu}-$ man Rights Centre, 2013). Most of the time those who are killed are close relatives of the perpetrators, who are often their own sons (Legal and Human Rights Centre, 2013).

Moreover, actual traditional faith healing and witchcraft are increasingly associated with the killing of and violence against people with albinism in African countries such as Tanzania. This phenomenon is particularly prevalent in the Lake 
Zone areas. Practitioners of witchcraft search for albino body organs in the belief that they can be used to create power and wealth, especially in business and politics (Marcom, 2013). Data have shown that most of the albinos who are attacked, killed and mutilated are women and children who are too weak to fight back (IRIN, 2010). In Tanzania, over 80 albinos have been killed since 2013 and more than 70 have been mutilated for their body parts (Zechenter, 1997). This practice has led to many people who are living with albinism leaving their economic activities, their homes and villages for their safety, and many have migrated to special centers and urban areas for cheap labor to support themselves. Tanzania has ratified and incorporated the UN Anti-Trafficking Protocol and has voluntarily bound itself to fulfill the treaty's mandate. The government passed its first anti-human trafficking law in 2008. Apart from providing the trafficking offense, this legislation enumerates "severe trafficking" offenses: trafficking involving children or disabled victims, adoption for sexual or labor exploitation, and offenses committed by crime syndicates, groups of two or more persons, religious leaders, or other authority figures (Section 6 (2) of the Tanzania Anti-Trafficking in Persons Act of 2008).

This practice not only forces victims to run away or live like slaves in their own societies, but it also violates many other human rights. Article 16 of the Constitution of the United Republic of Tanzania guarantees the right to respect and security of a person - to him/herself, his/her family and his/her place. Therefore, torture, killings, and other harassments because of witchcraft beliefs and practices amount to a violation of this constitutional right. Additionally, Tanzania has legislation that criminalizes the practice of witchcraft as entrenched in the Witchcraft Act, 1928. Witchcraft practices are particularly criminalized by Section 3 of this Act while Section 4 criminalizes accusing someone of witchcraft practices. However, Section 4 criminalizes the accusation of witchcraft only when the accusation is not made to the proper authorities. Sections 5(1) and 5(2) of this legislation provide for punishment in relation to the accusation of witchcraft. The Witchcraft Act punishes those practicing witchcraft as well as those who accuse someone of practicing witchcraft. This law does not deal with the challenges resulting from the practice of witchcraft, especially when there have been violations of human rights. Apart from that, this law does not provide a clear definition of witchcraft. Section 2 of the Act defines witchcraft as follows:

It includes sorcery, enchantment, bewitching, the use of instruments of witchcraft, and the purported exercise of any occult power and the purported possession of any occult knowledge.

This definition seems to focus on the occult and the existence of power rather than on the effects of the act (Mesaki, 2010). A major challenge of depending on legislation to curb a violation such as accusing a person of practicing witchcraft is adducing evidence in a court of law (Legal and Human Rights Centre, 2013). The Witchcraft Act itself is a very old law enacted during the colonial period and inherited after independence. It is reported that killings related to witchcraft have continued to claim the lives of hundreds of Tanzanians and it was ranked as the second highest cause of abuse of the right to life, after mob violence in 2013 (HelpAge International Tanzania, 2008). Statistics indicate that a violation of the right to life due to witchcraft-related killing has been increasing. For example, 630 people were killed in 2012 compared to 765 people in 2013. Moreover, of those killed in 2013, 505 were women, while 260 were males (Legal and Human Rights Centre, 2013). Women constitute the majority of people affected by witchcraft-related killings, 
especially in the regions of Shinyanga, Geita, Mwanza, Mbeya, Tabora, and Iringa (Legal and Human Rights Centre, 2013).

Therefore, more than a legal solution is needed to address this problem. The legal system alone does not provide a deep exploration of the realities of witchcraft, and therefore there is a need to educate society on the misconceptions about witchcraft and to take seriously the persecution of those who are suspected of practicing witchcraft, even to the full extent of the law. To curb this travesty, sensitizing citizens, religious organizations and civil society about witchcraft-related issues will enable the communities in Tanzania to understand the impact of persecuting people accused of practicing witchcraft. Such understanding may enable people to abandon beliefs in witchcraft practices as a means of solving their social issues. This cultural practice has also prevented Tanzania from honoring its international obligations under several international human rights instruments to which it is a signatory. Thus, it is violating several provisions of CEDAW, the Maputo Protocol, ICCPR, and UDHR.

Another African country that serves as an example of how human trafficking and belief in witchcraft have become interconnected is Nigeria. It is one of the largest hubs of human trafficking on the African continent, serving as both a destination and a transit point for trafficked victims from elsewhere in Africa and from around the world (Houreld, 2009). Some beliefs in witchcraft are particularly connected to the trafficking of children, especially street children, who form the largest proportion of the people who are trafficked from Nigeria. Street children are often accused of witchcraft, which makes them one of the most vulnerable groups to trafficking in Nigeria. They end up living on the streets after being abandoned by their families, having been accused of being witches (Harrop, 2012). Local pastors and community leaders have been blaming children for a variety of misfortunes, including accidents, divorce, and disease, and this often leads to their abandonment or sale to traffickers (Houreld, 2009). This problem is prevalent in the Nigerian state of Akwa Ibom. These children are left without familial or social protection; hence, they are placed at high risk of trafficking and exploitation. Incidents of trafficking involving both children and vulnerable adults are becoming common in areas where poverty is rampant as people are looking for a way to escape their harsh circumstances or for an excuse to distort beliefs with the aim of exploiting vulnerable populations for financial gain.

A typical example happened in Eket, Nigeria, where a 9-year-old boy was accused of witchcraft by a local pastor (Houreld, 2009). To exorcise the evil, his family forced him to drink acid, which destroyed his intestines and caused his slow and painful death. In the Democratic Republic of Congo, there have been reports of extremist Christianity combined with elements of witchcraft and the traditional belief that is known as kindoki (Harrop, 2012). According to its followers, kindoki is a kind of witchcraft or possession by evil spirits. Earlier it was simply a way of warding off evil, but it is now used to perpetuate the belief that some children are possessed by an evil power that needs to be exorcised (Houreld, 2009). Pastors who promote the belief in child witches are accused of doing so purely for financial gain, as they are said to extract fees for "delivering" the children from evil. The United Nations Children's Fund (UNICEF) notes:

Earnings from a deliverance ceremony, and also during a regular service when the collection plate goes around, are not insignificant. ... For these pastor-prophets, 'detecting' child witches brings not only money, but also 
a certain social status and popularity that draw new members and clients, and lead to yet more income (Cimpric, 2010).

In other words, the "witch hunt" of children has become a lucrative business.

Another negative impact of witchcraft belief and its role in society, which has been directly linked to the prevalence of human trafficking, is called juju. This practice originated from cultural beliefs most often found in West Africa (Ruhfus, 2012). Juju is a ritual of "oath swearing" that traffickers use as a powerful weapon of coercion (Harrop, 2012). In the case of many trafficking victims, juju oaths are used to enslave the victim to the spirit world and the trafficker, allowing traffickers to psychologically control victims and make sure that they are obeyed. Many young girls who desperately seek an escape from grinding poverty are trafficked to Europe in the false belief that a lucrative job awaits them. Many of them incur massive debts to organized crime gangs who pay for their travel (Ruhfus, 2012). The juju oath-swearing ritual commits them to repay their debt under threat of physical and/or mental harm (Ruhfus, 2012). Repayment usually involves forced servitude. There is also evidence that an increasing number of children are being trafficked to the United Kingdom where their blood, which is forcibly taken, is used in juju rituals (Rogers, 2011). Traffickers threaten the children with death or curses if they try to resist or fight back (Rogers). According to the Nigerian National Agency for Prohibition of Traffic in Persons (NAPTIP), cultural beliefs have been twisted to ensnare hundreds of victims. Notably, $90 \%$ of the girls from the Delta and Edo states sent into slavery in Europe undertook secret oaths with the idea that these rituals would help protect them on their journey (Finnish Immigration Service Country Information Service, 2015).

Nigeria is a signatory to many international instruments that prohibit human trafficking and has ratified and incorporated them into its domestic laws, as was discussed earlier in this paper. For example, human trafficking is prohibited by Section 30 of the Nigerian Child Rights Act of 2003 and Section 13 of the new Nigerian Trafficking in Persons (Prohibition) Law Enforcement and Administration (Amendment) Act 2005, which seek to stop human trafficking in Nigeria. The latter Act prescribes a minimum of seven years' imprisonment or a minimum fine of 1 million Nigerian Naira for offenders. The Trafficking in Persons (Prohibition) Law also prescribes criminal punishment for any person found to have illegal custody of a child under the age of 18 , sexually abuses another person, or causes any person to be exploited. However, witchcraft practices not only ensnare victims, but also make it incredibly difficult to detain, prosecute, and ultimately stop traffickers (Cimpric, 2010). Even though the ILO estimates that there have been 3.7 million trafficked victims from Africa since 2011, there were fewer than 300 prosecutions and convictions for the crime in Africa, and only about 10,000 victims were even identified (Ruhfus, 2011). The fear of retaliation resulting from the oaths victims are forced to take and the abuse they endure during their capture make it almost impossible for the victims to trust their rescuers and identify their captors. Victims often feel unable to testify against traffickers due to the fear that they will break an oath and invite misfortune into their lives (AFRUCA, 2010).

Another problem is the silence that surrounds the rituals. While juju (witchcraft) is widely believed and practiced, it is rarely spoken about publicly. People think even talking about juju might lead to something bad happening to them (AFRUCA, 2010). This silence makes it difficult to investigate crimes and prosecute 
perpetrators. This strong belief in such oaths hinders the investigation and prosecution of the traffickers because the victims are convinced that they will face dire consequences if they speak out against their captors (AFRUCA, 2010).

\section{Child Marriage and Payment of Dowry}

Child marriage is deeply embedded in African societies, especially in Tanzania, Uganda, Kenya, Malawi, Zambia, the DRC, Rwanda, South Africa, Somalia, Sudan, Ethiopia, Burundi, and Mozambique (Warner, 2011). Girls are generally considered ready for marriage when they reach puberty. Moreover, marriage is viewed as a way to protect young girls from pre-marital sex and pregnancy. The latter are seen as undermining family honor and may decrease the amount of dowry a family may receive (Warner, 2011). As with trafficking, money changes hands, and in this case, it is the selling party that makes the payment in the form of a dowry (Girls not Brides, 2014). The practice of paying a bridal price allows traffickers to pose as potential husbands and this persuades greedy or desperate parents and guardians to exchange their daughters for financial advantage. The culture of dowry payment by the groom to the bride's family is a key incentive for many families to marry off their daughters, even at a very young age (Girls not Brides, 2014). Girls are forced against their will to marry men who may be much older, as long as they are rich and capable of paying a high dowry. Girls who reject or resist marriage are usually assaulted, verbally abused, or evicted from their homes by their families. Girls and women are often forced to flee their homes and families, and they end up running to urban areas for cheap and forced labor for survival.

Others, who are unable to escape these forced marriages, end up experiencing domestic violence and abuse from their husbands and/or their in-laws (Human Rights Watch, 2014). They experience assault, rape and some of them are abandoned by their husbands and left to care for their children without any financial support (Human Rights Watch, 2014). Many of these women end up living in a lonely and isolated marriage, confined to the house by domestic and child rearing duties or because their husbands and in-laws restrict their movements. Many arranged marriages of young girls condemn these brides to a life of near slavery. Forcing these young girls to marry a man whom their parents or an adult guardian selected, is tantamount to the sale of human beings who are too young to make an informed choice in the matter. In some tribes, men have a culture of booking a wife for themselves or their sons by paying a dowry to secure a wife while the mother is still pregnant if they believe that she will give birth to a beautiful girl (Girls not Brides, 2014). In the event the pregnant woman gives birth to a boy, the man waits for another pregnancy. He can demand to be given his wife when the girl is only 5 years old so that he can take care of her himself (Girls not Brides, 2014) Parents or guardians of trafficked children are often under an illusion and are unaware of the exploitation that their children will be subjected to (Human Rights Watch, 2014).

In some other African countries such as Tanzania, child marriage is legal. The Law of Marriage Act of Tanzania expressly provides for a different legal minimum age of marriage for males and females. Section 13 of this Marriage Act stipulates that the legal minimum age for marriage is 15 years for girls while it is 18 years for boys. Furthermore, this law under Section 13 (2(a) allows a girl of 14 years to get married with court permission in special circumstances that make the marriage desirable. However, the High Court of Tanzania finally nullified Section 13 of this law by declaring this section unconstitutional in the recent case of Rebeca Gyumi v. Attorney General (2016). The three High Court judges argued that the Marriage 
Act violated the girl's essential rights to equality, dignity, and access to education, and contravened Tanzania's Law of the Child Act. The High Court pointed out that while the Law of Marriages Act may have been enacted with good intentions in 1971, these intentions were no longer relevant because the effect of the Act now is to discriminate against girls by depriving them of opportunities that are vital for all Tanzanians. However, the law is still in use. The court gave the Attorney General one year from the date of the decision to amend that law, by for example designating 18 years of age as the minimum for anyone, boy or girl, to contract a marriage. The High Court decision based on Article 30(5) of Tanzania Constitution, which provides that once the court found the law in conflict with the Constitution, instead of declaring such law void it has

to decide to afford the Government or other authority concerned an opportunity to rectify the defect found in the law or action concerned within such a period and in such manner as the High Court shall determine, and such law or action shall be deemed to be valid until such time the defect is rectified or the period determined by the High Court lapses, whichever is the earlier.

However, on 20 July 2016, the Tanzania Government filed a notice of intention to appeal this decision by the High Court (Mhagama, 2016). Although the grounds for appeal have yet to be revealed, challenging this ruling indicates Tanzania's political unwillingness to repeal this law (Maddison, 2016). Though Tanzania adopted the Anti-Trafficking in Persons Act, it has not taken this kind of culture into account as one of the leading factors accounting for the trafficking of young girls (IOM, 2008).

In 18 African nations, the minimum age for marriage is either dissimilar among boys and girls or below 18 years of age. Sudan has the lowest minimum age of marriage at 10 for boys and adolescent girls for Muslim marriages (which are the most common), and 13 for girls and 15 for boys for non-Muslim marriages. In Burundi, Burkina Faso, Cameroon, Chad, Congo Brazzaville, Cote D'Ivoire, DRC, Gabon, Mali, Niger, Senegal, Seychelles, Sudan, and Zimbabwe, the minimum age for marriage different between girls and boys. In Malawi, Zambia and Guinea Bissau the minimum age of marriage for boys and girls is 15 and 16 respectively (Odala, 2013). The African tradition tends to regard children as economic assets. Children are gradually involved in supporting the family from a very tender age, often as young as six years (Kamala et al 2001). Children assist their families by looking after the cattle, child caring, herding, fetching wood and water, and relieving their parents, especially the mothers, by undertaking more urgent and important domestic tasks. Sometimes families withdraw children from school so that they can help with farming chores during high seasons because children are considered a family resource (Kamala, 2001). Fostered children, domestic workers, and young girls customarily fail to attend school or learn a trade because of their family workload (Kamala, 2001). Traditionally, child rearing is a shared and communal responsibility in Africa, especially in rural areas. Therefore, when the children who work on the farms enroll in schools, especially in the cities, it means valuable resources disappear. This happened in Gabon in 1998 when compulsory schooling and strict anti-child labor laws created a big demand for domestic labor (IOM, 2008). 
Countries in which this culture is prevalent are party to many international instruments that prohibit child marriage, child labor, and human trafficking. For example, child marriages are contrary to Article 2 of both CEDAW and the Maputo Protocol, both of which require states to embody the principle of the equality of men and women and to condemn discrimination against women in all its forms. The tradition of child marriage is also contrary to Article 10(f) of CEDAW and Article 12 (2) (c) of the Maputo Protocol, as both require states to take appropriate measures to eliminate discrimination in education by reducing female students' drop-out rates and organizing programs for girls and women who have left school prematurely. The practice of child marriage is also contrary to Articles 2(b) and 14 of the Maputo Protocol and Articles 12 and 13 of CEDAW, which condemn harmful practices that endanger the health and general well-being of women. Additionally, Article 1(c) (i) of the UN Supplementary Convention on the Abolition of Slavery and the Slave Trade and the Institution and Practices Similar to Slavery of 1956 prohibit any institution or practices whereby a woman, without the right to refuse, is promised in marriage for money or in-kind payment to her parents or another person. The dowry received by a parent who consents to the marriage of a girl under 18 years old violates this Convention.

The constitutionality of the customary practice of, demand for, and payment of, bride price was questioned in Uganda in the case of Mifumi (U) Ltd. \& Others $v$. $A G$, (2007), in which petitioners demanded that bride price as a condition precedent to a marriage, and a demand for, and payment of, bride price as a condition precedent to dissolution of marriage be declared unconstitutional. The court had to deliberate:

- whether the demand for payment of bride price fettered the free consent of persons intending to marry, as provided in Article 31(3) of Uganda's Constitution;

- whether bride price perpetuated conditions of inequality contrary to Article 21(1) and (2) of the Constitution of Uganda; and

- whether the refund of bride price as a condition precedent to dissolution of a customary marriage fettered the free consent of persons in marriage provided for in Article 31(3) of the Constitution of Uganda.

The court ruled that the cultural practice of bride price, or the payment of a sum of money or property by the prospective son-in-law to the parents of the prospective bride as a condition precedent to lawful customary marriage, is not unconstitutional per se. The court went on to clarify that Uganda's Constitution did not prohibit a voluntary, mutual agreement between a bride and a groom to enter into the bride price agreement. A man and a woman had the constitutional right to so choose. With regard to the refund of bride price, the Court agreed that the customary practice of the husband demanding a refund of the bride price in the event of dissolution of the marriage demeaned and undermined the dignity of a woman and would be in violation of Article 33(6) of the Constitution. The court ruled that the demand of a refund violated a woman's entitlement to equal rights with a man in a marriage and that a woman's contribution in a marriage could not be equated to any sum of money or property. The court argued that any refund would violate a woman's constitutional right to be an equal co-partner to the man. In light of this, the court ruled that it was not essential to declare the practice of bride price unconstitutional, because the Constitution of Uganda itself, under Article 50 and others that provide for equal rights, could adequately take care of any grievances related to this matter. 
This constitutional case was presided over by five judges. At one point Judge J. A. Twinomujuni, in a dissenting judgment, differentiated between bride price and dowry and found that the practice of the parents of the bride demanding payment on marriage and for the husband demanding its refund in the event of a divorce were unconstitutional. He concluded:

Article 33 (1) of the Constitution provides that women should be accorded full and equal dignity of the person with men. Yet under the custom of bride price, women are not treated as a human being but as chattels. They are priced so low that they are exchanged for a cow or a few cows, a pig or a few pigs, a goat or a few goats. Their price is fixed without reference to them. Many young men cannot marry because they have no property to pay for young women. A young woman is not at liberty to choose a man of her heart because if he has no property, she has no chance to marry him. Marriage is not an exercise of free consent as required by Article 31(3) of the Constitution. Bride price helps to perpetuate a belief in society that a man is superior to a woman, that once he buys a woman, he can batter her, humiliate her and treat her as he likes. In my humble judgment, I would hold that the custom of paying bride price in a customary marriage is repugnant to good conscience and contravenes Article 31(3) and 33(1) of the Constitution. It is high time that the custom is abolished and the woman should be set free.

Judge Twinomujuni thus found that the practice of demanding a refund of bride price dehumanized the woman and rendered her a similar to "a chattel that can be sold in a market." Moreover, he felt that the practice subjected her to potential humiliation, cruelty, torture, and degrading treatment. Moreover, such a woman would be subject to slavery and servitude, and it made it impossible for her to move out of an abusive marriage or cast aside her chains of slavery.

Most African domestic legislation does not recognize the payment of dowry and child marriage as offenses (Warner, 2011). Conversely, other African countries have managed to overcome this culture by amending their constitutions to stipulate the legal age of marriage. These countries include Uganda, whose Constitution affirms that a man and a woman are entitled to marry only if they are 18 years of age or older. At 18, young men and women are entitled to equal rights in a marriage, during the marriage, and at its dissolution (Article 32 of the Constitution of the Republic of Uganda, 1995). Similarly, the Namibian Constitution states:

Men and women of full age, without any limitation due to race, color, ethnic origin, nationality, religion, creed or social or economic status, shall have the right to marry and to found a family. They shall be entitled to equal rights as to marriage, during marriage, and at its dissolution. (Article 14(1) and (2) of the Constitution of the Republic of Namibia of 1990.)

In February 2005, Algeria raised the minimum age of marriage from 18 years for women and standardized the age to 19 years for both men and women in Article 7 of Algeria Family Code, 2005. In line with these standards, 32 African countries have set the minimum age of marriage at 18 for both girls and boys. These are Angola, Benin, Botswana, Cape Verde, Central African Republic, Comoros, Djibouti, Egypt, Eritrea, Ethiopia, Gambia, Ghana, Guinea, Kenya, Liberia, Madagascar, Mali, Mauritania, Mauritius, Morocco, Mozambique, Namibia, Nigeria, Sao Tome, Sierra Leone, Somalia, South Africa, South Sudan, Togo, 
Tunisia and Uganda (Odala, 2013). Countries such as Lesotho, Libya, and Rwanda stipulate that the minimum age of marriage is 18 for both girls and boys (Odala, 2013).

\section{Female Genital Mutilation (FGM)}

Female genital mutilation refers to all kinds of procedures that involve partial or total removal of the external female genitalia or other injury to the female genital organs for non-medical reasons (WHO, 2013). FGM is also called female genital cutting (FGC). UNICEF conducted a study of this practice in 2013 and found that FGM culture is mostly practiced in 29 countries in Africa. In the Middle East, Egypt has the region's highest total number of women (27.2 million) who have been subjected to FGM, while the highest percentage (98\%) of FGM has occurred in Somalia. Other countries (mostly in Africa) that practice this include Benin, Burkina Faso, Cameroon, Central African Republic, Chad, Côte d'Ivoire, Djibouti, Egypt, Eritrea, Ethiopia, Gambia, Ghana, Guinea, Guinea-Bissau, Iraq, Kenya, Liberia, Mali, Mauritania, Niger, Nigeria, Senegal, Sierra Leone, Somalia, Sudan, Togo, Uganda, Tanzania, and Yemen (UNICEF, 2013). According to the report, FGM involves children aged eight to 15 and is done particularly as a rite of passage to prepare girls for marriage (UNICEF, 2013). It is usually carried out by traditional practitioners, while in urban areas it is sometimes performed by midwives and doctors (28 Too Many, 2013).

The idea behind FGM is to control the sexual desires of girls so that they will be satisfied with their husbands only (28 Too Many: Galukande, 2015). It is also believed that it allows men to have easy intercourse with their wives (Wambura \& Khaday, 2010). These communities consider FGM important for their family's dignity and for bringing glory, and girls who have undergone FGM are respected and gain higher status and recognition in the community. Moreover, the perception is that such girls will be able to marry rich, be respected, and have caring husbands. Some of the tribes in Tanzania, such as the Nyaturu, Gogo and Maasai, perform FGM believing that it cures lawalawa, which is a treatable vaginal or urinary tract infection (GIZ, 2011). In other places in Tanzania, such as Manjaro district in the Manyara region, it has been associated with business initiatives as even older women have reportedly undergone FGM for financial reward (GIZ, 2011). After undergoing FGM, these women dry the removed flesh and sell these bits as charms to mining traders and other merchants, as it is believed that the dried flesh will bring luck and fortune to their businesses (GIZ, 2011).

The communities that practice FGM put girls under strong social pressure. Pressure is also brought to bear by peers, and girls risk victimization and stigma if they refuse to undergo FGM. Girls and women who refuse to undergo FGM are neither respected nor married, and one can be divorced if, after marriage, it is discovered that she was not circumcised (Galukande, 2015). The taboos surrounding girls who have not undergone FGM affect their daily activities. For example, girls who refuse to submit to this procedure are prohibited from cooking for inlaws, washing in the river with girls who have undergone FGM, and opening the doors/gates of cow shelters. The latter taboo is applied to prevent the girl from bringing bad luck upon anyone who may enter the shelter after her (Children's Dignity Forum, 2010). Some women may be subjected to FGM after marriage when 
they experience problems conceiving children, or if the husband's family faces difficulties or misfortune, believing that the couple is responsible for their ill fate (Children's Dignity Forum, 2010).

This kind of social exclusion affects girls' and women's ability to continue to live in their communities, and most of them opt to flee from rural to urban areas where they end up being engaged in forced labor and/or prostitution (UNHCR, 2009). Some of the girls manage to escape and emigrate or migrate from their country of birth. In this context, FGM has been identified as a legitimate basis for granting asylum by the Council of Europe Parliamentary Assembly in its Report Document No. 12350 of July 26, 2010. The Council calls upon member states to ensure that gender-based violence and gender-related persecution are appropriately taken into account in any asylum determination process. The UNHCR's Guidance Note reads:

A girl or woman seeking asylum because she has been compelled to undergo, or is likely to be subjected to FGM/C, can qualify for refugee status under the 1951 Convention relating to the Status of Refugees (UNHCR, 2009)

The UNHCR Guidelines consider FGM/C to be a form of gender-based violence that inflicts severe mental and physical harm and amounts to persecution (UNHCR). The relationship between FGM culture and trafficking of girls has been well reported by Kenyan journalist Diana Kendi in her nine-minute film titled "The Bondage of Culture," which was the winner of the first annual Efua Dorkenoo Pan African Award for Reportage on FGM (UNFPA \& The Guardian, 2016). The film features the stories of five survivors of FGM living in West Pokot County, Kenya where, despite a 2011 Kenyan law banning FGM nationally, the procedure remains prevalent (UNFPA \& The Guardian, 2016). The film also includes commentary from a former circumciser in the area who now advocates ending FGM, a head teacher at a school that houses young victims of the practice who have fled their homes, and a local assistant chief who helps rescue the girls, among others. One unnamed 13-year-old girl, with her face blurred, narrates how she was forced to marry shortly after suffering female genital mutilation (FGM):

My father forced me to get married to an older man almost his age. The old man gave him 20 cows. I tried to run away from that old man, but my father warned me that he would beat me to death if he was forced to return the cows he was given as payment for dowry" (UNFPA \& The Guardian, 2016).

This traditional practice, which affects the physical and psychological health of girls, impacts their right to equality as it affects their performance and attendance at school by up to $25 \%$. It is for this reason that such girls become economically less self-reliant and insecure (WHO, 2006). Additionally, the FGM process is conducted not only under unhealthy conditions but also in an unsafe manner, causing some children to die from excessive bleeding. Circumcisers often use sharp equipment such as stones, local knives, and razor blades that are at times rusty. The same instrument is used to circumcise all the initiates, thus subjecting the victims to tetanus and HIV (Galukande, 2015). Other complications include severe pain, hemorrhaging, shock, urine retention, bacterial infection, open sores in the genital region, and injury to nearby genital tissue (WHO, 2006). Recurrent bladder and 
urinary tract infections, infertility, cysts and childbirth complications are among the long-term complications (WHO, 2006). FGM as a kind of gender-based violence has been recognized as harmful and a violation of the human rights of girls and women by the Maputo Protocol. Article 5(b) of the Maputo Protocol specifically requires States to prohibit and eradicate all forms of FGM. International norms also require States to prohibit and condemn FGM by taking appropriate measures, including legislative measures that are backed up by sanctions; creating public awareness; providing necessary support to the victims of FGM; and protecting women who are at risk of being subjected to harmful practices (Article 1(b), 2, and 5 of Maputo Protocol and Article 5 of CEDAW). The FGM culture hinders the free development of the victims and degrades their dignity and respect as guaranteed by Article 3 of the Maputo Protocol and Article 3 of CEDAW. The practice is also contrary to international instruments that aim to protect women's right to health. The latter includes sexual and reproductive health and the right to be protected against sexually transmitted infections and HIV (Article 14 of Maputo Protocol and Article 12 of CEDAW).

Most countries that practice FGM have managed to incorporate CEDAW and the Maputo Protocol on FGM. Countries such as Tanzania amended their Penal Codes to prohibit FGM of girls under the age of 18 in 1998. Some of the communities that used to practice FGM have abandoned it, and their girls are undergoing alternative rites of passage (ARP) ceremonies instead (Waritay \& Wilson, 2012). Although there have been arrests in some African countries for this offense, prosecution of the perpetrators has been slow (Legal and Human Rights Centre, 2004). This is because law enforcers are generally unaware of the law and its intention, and therefore don't take FGM seriously. A good example of the reasons for a low conviction rate is the case of Zakayo Katungo $v$. Selemani Ningoli (2002), which occurred in Tanzania. In this case, the accused was acquitted after the police failed to proceed with the case due to a lack of credible evidence, which was supposed to be collected by the police themselves (Legal and Human Rights Centre, 2004). The evidence involved a doctor's report, which was supposed to have been taken at the time the matter was reported to the police. However, the police did not take any measures to take the victim to the hospital for that purpose (Legal and Human Rights Centre, 2004).

The ineffective enforcement of both international and domestic laws that are violated by the FGM culture is due not only to the ignorance of the law enforcers themselves but also because FGM occurs in secret, which makes detection difficult (Msuya, 2002). The fear of prosecution is driving the practice underground in some regions, while in other areas FGM is still practiced with little or no law enforcement (28 Too Many, 2013). In Tanzania, in areas such as Kilimanjaro and Manayara, FGM is done to baby girls between one month and one year old to avoid detection, while initially it was done to girls between the ages of eight and 18. It has also been reported that girls from Tanzania are taken across the border to Kenya to be circumcised (Waritay \& Wilson, 2012). Various NGOs in Africa are working hard to combat FGM through different strategies, including the human rights approach, a health risk approach, and women's empowerment (Batha, 2016). There is a need to introduce ethnic heritage into the African school curriculum to help young girls to develop self-realization (i.e., freedom from external coercion, including cultural expectations and political and economic freedom) to counter negative cultural coercion and help them make their own constructive decisions. The role of men in stopping FGM in Africa is also crucial. Moreover, men 
need to help tackle the epidemic of trafficking and the commercial sexual exploitation of women and girls because Africa is a deeply patriarchal society. This was urgently recommended by a Nigerian law student and anti-FGM activist, Kelechukwu Nwachukwu, who argues that FGM will not end until men also get behind efforts to eradicate it. In the activist's words, "It's almost impossible to end it without engaging men because they are the decision makers and gatekeepers in the community" (Betha, 2016).

\section{Gender Inequality, Male Dominance, and the Preferential Treatment of Sons}

An in-depth understanding of trafficking goes hand in hand with gender roles and the relative values ascribed to females and males in a community. Gender shapes the way power and violence are used in African society. Hence it may also shape the way it is perceived in the context of human trafficking (Batha, 2016). Most research concludes that girls and women are at high risk of being trafficked in Africa and removed from school to provide income for the family, while boys are favored for educational opportunity (Osarenren, 2008). In many countries in Africa, a preference for sons is a powerful tradition (Save the Children, 2003). Societies generally view females as inferior and subordinate to males (Lea Rouanet, 2015). Historically, the social structure reflects subordination of females, and this subordination occurs within the origin and conduct of warfare, the hierarchical ordering of influential religions, institutions, attribution of political power, the authority of the judiciary, and influences that shape the content of the law (Osarenren, 2008). The male preference tradition in Africa begins early in life at the first sign of pregnancy, when a woman receives unsolicited prayers from her husband and the husband's family for the safe delivery of a baby boy (Mulema, 2014). Usually, the birth of a son is welcomed with celebration as an asset, whereas that of a girl is seen as a liability and an impending economic drain (Mulema, 2014). There is a saying that "Bringing up girls is like watering the neighbor's garden," which means that eventually a girl will be married and become a member of another family, so investing in her is like working for the benefit of others (Save the Children, 2003). Thus, in response to the attitudes and behaviors that reinforce women's subordination, a pregnant woman also wishes that her first-born will be a male child (Mulema, 2014). In the hope of giving birth to a son, women who have only daughters are likely to keep on bearing more children than initially planned (Osarenren, 2008). This culture prompts some men to marry a second or a third wife so they can have a male child. This culture manifests itself in deprivation, neglect and discriminatory treatment of daughters to the detriment of their mental and physical health (Osarenren, 2008).

Underlying these practices among many families in Africa are differing social roles ascribed to men and women (Mulema, 2014). Sons are preferred because they perpetuate the family name while girls lose their identity upon marriage by adopting their husbands' names. Many families wish to have a son to preserve their family name. Sons usually take responsibility for the care of aging parents and perform their parents' burial rites (Mulema, 2014). The economic obligations of sons toward parents are greater-a son is considered the family pillar who ensures continuity and the protection of the family property. They are to provide labor and to bring in a bride, who will be an extra pair of hands in the household. Sons are also preferred because of inheritance. Unlike daughters, they are the heirs to their fathers' property (Mulema, 2014). In most traditional societies, women are not allowed to inherit property, so male members retain and control the rights to the 
property. Therefore, not having a son is viewed as a source of vulnerability for parents in Africa, while having daughters only attracts social stigma.

The preferential treatment of sons (i.e., son preference) is a principal form of discrimination, which has far-reaching implications for women. It denies the girl child good health, education, recreation, economic opportunity, and the right to choose her partner. Sons' preference culture violates Articles 3, 4, 10 and 12 of CEDAW, Articles 2, 3, 12, 13, 14 and 15 of the Maputo Protocol, and Articles 2, 6, $12,19,24,27$ and 28 of the Convention on the Rights of the Child. A female child is disadvantaged from birth in terms of the quality and quantity of parental care and investment in her development. Son preference has affected other spheres such as nutrition and education. In most homes, sons are given bigger portions of food than daughters are, and are more likely to be enrolled in better schools and encouraged to complete their studies (Osarenren, 2008). When funds are short, girls are normally withdrawn from school to allow for sons to be educated, irrespective of whether the girls are naturally intelligent and the sons are dull (Osarenren, 2008). Son preference has thus led to acute discrimination, particularly in resource constrained societies where extreme cases prompt selective abortion and female infanticide in these days of technology. Therefore, in countries such as Tanzania, pre-natal sex determination and disclosure are not illegal, and there is no law banning abortion for sex selection. The educational and economic implications of son preference are huge. For example, there are far fewer females than males enrolled in high schools in Africa, despite substantial increases in the number of women who have attained at least seven years' primary education (Mulema, 2014). This inequality between males' and females' access to education causes a lifelong economic and social disadvantage to women.

However, access to education by itself is not enough to eliminate values held by society because those values have been integrated into educational curricula and textbooks. Women are portrayed as passive and domestically oriented, whereas men are portrayed as dominant and breadwinners. Young girls in rural and poor urban homes are burdened with domestic tasks and childcare, which leaves them with no time to play, while young boys have to meet fewer demands and are allowed to engage in activities outside the home (Mwangeni et al, 2001). The Convention on the Rights of the Child guarantees the rights of all children and requires that States that ratified this Convention recognize children's right to rest and leisure and to engage in play and recreational activities because recreation plays a vital part in a child's emotional and mental development. However, the status of girls is linked to that of women, and it is common knowledge that a woman's work never ends, especially in rural areas and in poor urban households. In Africa, women have fewer livelihood options, particularly as they are less likely to possess land and capital. Childhood experiences of discrimination have a strong bearing on adult men's and women's attitudes and behavior with regard to masculinity and control. Son preference thus reinforces a girl's low self-worth, low self-esteem, depression, and eventually low productivity in adulthood.

In societies where son preference is strong, this culture has a negative impact on women's social development. The status of women is generally low where their security and status depend on their ability to produce sons (Mulema, 2001). The more sons a woman produces, the higher is her security and status among her inlaws and her community. This culture affects women's social development potential not only within the immediate family and community but also at a national 
level. Lower proportions of women than men are found in higher educational institutions, high-status occupations, and top managerial and administrative positions in Africa. Because childbearing is directly a woman's concern, men's son preference may also be deleterious to women's reproductive health. Efforts to fulfill their husbands' desire for sons may require women to bear additional children. Repeated childbearing may not only affect their physiological well-being but may also increase their morbidity and mortality risk (Osarenren, 2008). This culture that puts huge pressure on women to produce sons not only directly affects women's reproductive decisions with implications for their health and survival, but also puts women in a position where they must perpetuate the lower status of girls (Osarenren, 2008). Some women bear consequences of giving birth to an unwanted girl child, including abandonment, divorce, violence, or even death (Mwangeni, 2001). Men continue to be the primary decision-makers in both public and domestic life, and they are the income earners. Thus reproductive intentions are substantially influenced by their preferences (Mwangeni, 2001). Thus, their low status and the vicious cycle 'that keeps women in their place' leave women and girls with limited economic options and increase their vulnerability to exploitative forms of exclusion. It limits their ability to effect change, to challenge discrimination, or to safeguard themselves against traffickers of all kinds. In this context, it is noteworthy that the economic empowerment of women is seen as a key factor for anti-trafficking strategies (Mikhai, 2002).

Women's vulnerability is also reflected in unemployment. In Africa, women have fewer livelihood options, particularly as they are less likely to have land and capital and are paid lower wages. This prompts them to seek opportunities by migrating. There is evidence of women migrating to find domestic work in many regions (Pearson, 2003). Some African cultures have denied women the right to own property upon divorce or the death of their husbands (Mikhai, 2002). In Tanzania, it has even been codified into enforceable law. There are three different laws applicable for inheritance in Tanzania. The first one is the Indian Law of Succession Act of 1865 , which provides for one-third of the estate to pass to the widow and twothirds to the children. If there are no children, then the widow is entitled to half of the estate and the other half passes to the deceased's parents or other blood relatives. Another law of inheritance is Islamic law, which provides for widows to receive one-eighth of the deceased husband's property if there are children, and onefourth if there are no children. The third law of inheritance is customary law, under which a widow cannot inherit any property of the deceased husband (Mikhai, 2002). Upon being denied the right to property after divorce or the death of their husbands, women are usually left with few options and sometimes with no place to live at all. Hence, they are forced to migrate and thus become vulnerable to trafficking. Gender-based discrimination leads to gender violence as well (Mikhai, 2002). This happens when the community condones violence by the husband against his wife and women end up with no alternative but to leave home to escape abuse (Pearson, 2003). Many African societies consider domestic violence to be a private matter. A man can justifiably abuse his wife in any circumstance without fear of punishment. In any case, neither the victims nor law enforcement agencies are willing to bring the matter before the court. African women and girls also have been punished and shamed once they became pregnant outside the marriage or without being married (Pearson, 2003). Families consider the burden posed by grandchildren borne to unmarried daughters as among the reasons for preferring sons. Many daughters who become mothers without stable partners continue to 
live with their parents. Unable to achieve economic independence, they become a financial burden. They feel forced to leave their homes, or sometimes they are chased away by their parents (Mulema, 2014).

However, to successfully address the underlying issue of son preference is challenging huge challenge and requires a multifaceted approach. The government needs to initiate programs to challenge men's attitudes toward a one-sex family composition. Men should be educated about and persuaded that children of both sexes are equally important. Such measures can assist men to reconsider biases toward one sex, to minimize marital problems, and to improve women's status. Supportive measures for girls and women, such as incentives for families with only daughters and other legal and awareness-raising actions are also needed. States should support and advocate awareness-raising activities that stimulate discussion and debate on the concept of equal value of boys and girls. Most African countries do not have foster or safe houses for the victims of domestic violence, which contributes to victims continuing to live like slaves in their communities. Not having places of safety to run to has led many of the victims of these cultures to subject themselves to prostitution and/or forced labor for their survival (Mulema, 2014). The male dominant culture seems to have affected even the law enforcers whose decisions are sometimes clouded by their own adherence to a discriminating culture, even when the matter is well covered by the constitution of the country and international laws. The best example is the Tanzania case of Elizabeth Steven and Another v. Attorney General (2005). In this case, the petitioners filed a petition under Article 30(3) of the Constitution of the United Republic of Tanzania, 1977, for an order declaring paragraphs 1 to 51 of the second schedule of the Local Customary Law unconstitutional. This section denies women the right to inherit land and gives males preference over females. Through the services of their advocates, the petitioners requested the court to consider Section 13 of the Tanzanian Constitution, which provides that:

All persons are equal before the law and are entitled, without any discrimination, to protection and equality before the law.

The petitioners also referred the court to a litany of international treaties that Tanzania had ratified, such as CEDAW of 1979, ACHPR of 1981, the Convention on the Rights of the Child of 1989 (CRC), and the International Covenant on Economic, Social and Cultural Rights of 1966 (ICECSR) which, among others, provides for the elimination of discrimination against women. The petitioners invited the court to consider international treaties as an additional obligation to the law of the country and to acknowledge that their ratification was not merely a formality. The court could not decide in favor of the complainants based on these international instruments, nor could they employ the Constitution of Tanzania, claiming that a court of law was not the place for eliminating customary law and that customary law should be left to pass away with time.

Most African countries have provisions of gender equality in their constitutions. (Truong, 2006). Some, such as Kenya, Rwanda, Ghana and South Africa, have gender responsive constitutions that address discriminatory practices against women that are rooted in the negative interpretations of custom, tradition, and religion. For example, Uganda, Rwanda and, to some extent, Kenya have unified the law of inheritance, which makes it easier for their citizens to access the law (TAWLA, 2013). These countries not only unified inheritance law, but they have 
also taken equality into account. The constitutions of South Africa and Kenya create a hierarchy among the right to culture, principles of equality, non-discrimination, and recognition of customary law. The Kenyan Constitution also eliminated gender discrimination in relation to land and property under Article 60(1) (f), which gives everyone, including women, the right to inheritance and an unbiased right to own land. The Ghanaian Constitution also provides that customary law is only applicable if it is so pronounced by the court. However, practice has shown that courts in Ghana apply only positive customs (TAWLA, 2013).

\section{Conclusion}

Trafficking of women and children in Africa is a serious international crime that can only be curbed by proper enforcement of national and international trafficking laws and the eradication of cultural traditions that are harmful to women. This is necessary to protect those who are vulnerable and being harmed by cultural practices. Inadequate implementation of these laws constitutes a major challenge in countries on the African continent. The ineffectiveness of criminal justice systems and related institutions in combating human trafficking has also resulted in few successful prosecutions and convictions of traffickers. The 2014 Global Report on Trafficking in Persons of the UN Office on Drugs and Crime indicates that only four in 10 countries reported having 10 or more yearly convictions, with nearly $15 \%$ having no convictions at all. According to the US Trafficking in Persons Report of 2014, the Sub-Saharan African region had only 574 human trafficking prosecutions and 341 convictions in 2013 (Departments of State, United Sates of America, 2014). This clearly demonstrates that law enforcement officials need to be able to recognize trafficking when they see it because, if they do not, they may ignore a case or take inappropriate measures. Reports have shown that some law enforcers harass rather than help victims, especially those engaged in prostitution (Pearson, 2003). More often than not, the media in Africa report on misdemeanors and criminal acts that are rooted in cultural practices without referring to them as human trafficking because people are still ignorant of the realities of this phenomenon and the causes of it (Lillie, 2013). We have to acknowledge trafficking when it occurs and increase own knowledge and awareness of this phenomenon.

In countries like Kenya, victims who engage in livelihoods that have been criminalized, such as hawking and begging, are reportedly harassed by law officials (IOM, 2008). Additionally, some victims are unwilling to support the investigation and prosecution of human trafficking cases due to fear of being arrested or deported because of their involuntary participation in criminal activities or irregular status (IOM, 2008). It is clear that cultural practices are so highly valued that they are allowed to violate the rights of human beings. Notably, culture is not static in any given society; it is ever changing and evolving, depending on the changing needs of that society. Culture is value-driven and helps to maintain values, structure, and unity within a society, but it can never supersede the law or a person's humanity and individual autonomy. Culture can never and should never be used as an excuse to violate a person's inalienable human rights. If any given cultural practice has evolved into something harmful, there needs to be a serious dialogue to begin to understand the changing function of that particular practice and the needs of that society in relation to that society's culture. This is necessary to protect those who are vulnerable and being harmed by this practice, particularly women and children. 
The public, governments and law enforcement agents do not have sufficient knowledge and awareness of all aspects of human trafficking. Moreover, awareness of the extent to which organized criminal groups are involved in trafficking, and the dire fate of the victims is nebulous at best. Human trafficking remains a crime. Sadly, the victims are unlikely to press charges against the perpetrators because they do not know that they are in fact victims of human trafficking. The existing body of knowledge about human trafficking should, therefore, be extended to raise public consciousness about the issue as a matter of urgency. Clearly, current knowledge is still not enough to give support to comprehensive programs for action which should address the different dimensions of human trafficking as a problem. Many aspects of human trafficking remain poorly understood even though it is now a priority issue for many African states. Information available on the magnitude of this problem is still limited. Knowledge about the intersection of migration and trafficking has not yet brought about any consensus on the underlying forces and their implications for the well-being of children and women (Osarenren, 2008).

The efforts of ending traditional practices which are harmful to women need to involve men who are perpetuating and benefiting from these harmful practices. Men need to be engaged because of the role they play in the societies, as community leaders, providers, and heads of families. For that reason, they are in great position to enable the eradication of harmful practices which facilitate women and children trafficking and slavery in Africa. Systematic encouragement and support of collective action among the women themselves must be applied to eliminate such harmful cultures. Women need to have a sense of self-worth and empowerment to be able to act in their own self-interest with respect to their human rights (Mubangizi, 2016). Therefore, women collective action requires the creation of bonding networks among African women themselves, including those in urban areas. It also requires that their voices be heard by governments and other stakeholders. Apart from eliminating harmful traditional practices, efforts to eradicate trafficking of women and children must target problems such as corruption, poverty, lack of educational and employment opportunities and the demand which drives the market.

\section{ACKNOWLEDGMENTS}

With the permission of the reviewers and the author, Dignity thanks the following reviewers for their time and expertise: Esohe Aghatise, executive director of Associazione Iroko Onlus and visiting lecturer, United Nations Interregional Crime and Justice Research Institute (UNICRI) and University of Turin Department of Law, Italy, and Despina Learmonth, PhD, University of Cape Town, South Africa.

\section{AUTHOR BIOGRAPHY}

Norah Hashim Msuya was born in Kilimanjaro, Tanzania. She received the L.L.B. degree from Tumaini University Iringa, Tanzania in 2005 and the LL.M degree in International Law from the University of Dar es Salam, Tanzania in 2010. In November 2005, she joined the Faculty of Law of Mzumbe University as Tutor, and has been an Assistant Lecturer since 2010. She is also a practicing Advocate of the High Court of Tanzania and subordinate Courts therein, save the Primary Court. Norah is also the Coordinator and Founder Member of Tanzania Legal Aid Organization for Women and Children, a non-governmental organization that provides legal assistance and education to women and children in 
Tanzania. Her current research interests include women's rights, children's rights, and labor law. She is a Fellow of the Tanzania Women Lawyers Association (TAWLA), Tanganyika Law Society (TLS) and East Africa Law Society (ELS). She is currently a thirdyear Ph.D. candidate in the School of Law at the University of KwaZulu Natal, South Africa, doing LL.D in human rights law and a part-time researcher at the African Ombudsman Research Centre (AORC).

\section{RECOMMENDED CITATION}

Msuya, Norah Hashim. (2017). Tradition and culture in Africa: Practices that facilitate trafficking of women and children. Dignity: A Journal of Sexual Exploitation and Violence. Vol. 2, Issue 1, Article 3. DOI:10.23860/dignity.2017.02.01.03. Available at http://digitalcommons.uri.edu/dignity/vol2/iss1/3.

\section{REFERENCES}

28 Too Many, Country Profile: FGM in Tanzania. 28 Too Many (2013).

Abdelkader GK \& Zangaou M. Wahaya, Domestic and Sexual Slavery in Niger, AntiSlavery Report 2012 available at http://www.wahaya_Report_eng.Pdf.

Adepoju A., (2005) Review of research and data on human trafficking in Sub-Saharan Africa, in Laczko, F. and E. Gozdziak (eds), Data and Research on Human Trafficking: A Global Survey, IOM, (2005) Geneva.

African Children's Committee: Committee on the Rights of the Child examines the report of Ghana (2015) http://www.ohchr.org/EN/NewsEvents/Pages/

DisplayNews.aspx?NewsID =15987\&LangID=E. Accessed on 4 July 2016.

African Children's Committee on the Rights of the Child (ACCRC), (2015). Available at http://www.ohchr.org/EN/NewsEvents/Pages/DisplayNews.aspx?NewsID=1598 7\&LangID=E. Accessed July 4, 2016.

Algeria Family Code, 2005.

ILO Abolition of Forced Labor Convention (Convention No. 105 of 1957).

Ameh R.K., Reconciling human rights and traditional practices: The anti-trokosi campaign in Ghana, 19 Canadian Journal of Law and Society (2004) 51-72.

Asomah Y., Cultural Rights Versus Human Rights: A Critical Analysis of the Trokosi Practice in Ghana and The Role of Civil Society, African Human Rights Law Journal, Vol. 15, No. 1 (2015) 29-149.

Ayton-Shenker D., The challenge of human rights and cultural diversity (1995) Available at http://www.un.org/rights/dpi1627e.htm. Accessed July, 302016.

Banda F., Women, Law and Human Rights: An African Perspective, Hart Publishing, (2005) 248.

Batha E., "Female genital mutilation is a men's issue, say African activists," Reuters May 17, 2016.

Beirnauer J., "West-African Court Slavery Judgement," INTERNATIONAL Union Rights Volume 16, Issue 2 (2009) 18-19.

Bhe v The Magistrate of Khayelitsha 20051 SA 580 (CC).

Children's Dignity Forum, Voices of Child Brides and Child Mothers in Tanzania, Peer Research Report on Child Marriage in Tarime District, Mara Region, Tanzania (2010). www.forwarduk.org.uk/download/194 
Constitution of the Republic of Namibia, 1990.

Constitution of the Republic of South Africa, 1996.

Constitution of the Republic of Uganda of 1995.

Constitution of Zimbabwe of 2013.

Convention against Torture and other Cruel, Inhuman or Degrading Treatment or Punishment of 1984.

Convention to Suppress the Slave Trade and Slavery and the Supplementary Convention on the Abolition of Slavery, the Slave Trade, and Institutions and Practices Similar to Slavery of 1926.

Covenant on Economic, Social and Cultural Rights of 1966

Department of Justice, Constitutional Development: Gender Directorate, South Africa. 'Ukuthwala- Let's Stop Stolen Childhood' (2010) Available at http://webcache.googleusercontent.com/search?q=cache:tvPj1FgAXKgJ:www.ju stice.gov.za/brochure/ukuthwala/ukuthwala.html+\&cd=1\&hl=en\&ct=clnk\&gl=za 1. Accessed on July 20, 2015.

Department of State, United Sates of America, Trafficking in Persons Report, June 2014. Available at http://www.state.gov/documents/organization/226844.pdf. Accessed on July 12, 2016.

Elizabeth Steven and Another V. Attorney General, 282High Court of Tanzania at Dar es Salaam: Miscellaneous Civil Cause No. 82 of 2005 (Unreported).

Galukande M., Eradicating female genital mutilation and cutting in Tanzania: An observational study, BMC Public Health 10.1186/s12889-015-2439-1 Nov (2015).

Ghana Human Trafficking Act, 2005.

Girls not Brides, Child Marriage around the World: Tanzania (2014). Available at http://www.girlsnotbrides.org/child-marriage/tanzania/. Accessed on September 27, 2015

Gumede v President of the Republic of South Africa 2009 3BCLR 243 (CC).

Hadijatou Mani Koraou v The Republic of Niger. Community Court of Justice of the Economic Community of West African States (ECOWAS), suit ECW/CCJ/APP/0808, judgment ECW/CCJ/JUD/06/08, 27 October 2008.

Hamman M., Ukuthwala, Human Trafficking \& The Media, Media Monitoring Africa, (2014) Available at http://www. mediamonitoringafrica.org/images/uploads/UkuthwalaHuman\%20TraffickingM edia.pdf. Accessed on October 27, 2015

Harrop, E.W, Ties that bind: African witchcraft and contemporary slavery, Liberty and Humanity (2012) available at http://libertyandhumanity.com/themes/humantrafficking/ties-that-bind-african-witchcraft-and-contemporary-slavery/ Accessed on January 24, 2016.

HelpAge International Tanzania: NGO Thematic Shadow Report on Older Women's Rights in Tanzania, A Report Submitted to the 41st session of the Committee on CEDAW in relation to Tanzania's Combined fourth, fifth and sixth periodic report of States parties, April 16, 2007 (CEDAW/C/TZA/6) April 2008.

Houreld, K . African children denounced as witches by Christian Pastors. Huffington Post, (2009) Retrieved from http://www.huffingtonpost.com/2009/10/18/african-childrendenounce_n_324943.html on June 6, 2015.

Human Rights Watch, No Way Out: Child Marriage and Human Rights Abuses in Tanzania, Human Rights Watch. (2014).

Idang GE., African culture and values, Phronimon Vol.16 No.2 Pretoria (2015) 97-111.21 
Internationale Zusammenarbeit (GIZ) "Female Genital Mutilation in Tanzania" Country Fact Sheet Ending Female Genital Mutilation (2011).

IOM Research Assessment and Baseline Information in Tanzania, Kenya, Uganda, and Burundi, (2008) IOM.

IRIN, "Child witchcraft allegations on the rise" (2010) Available at http://www.irinnews.org/report/89858/rights-child-witchcraft-allegations-rise Accessed on 10 July 2015.

Jean A., Hadijatou Mani Koraou v. Republic of Niger. Judgment No. ECW/CCJ/JUD/ 06/08. (2009). The American Journal of International Law, 103(2), 311-317.

Kamala E, Lusinde J, Millinga J, Mwaitula, J, Gonza G \& Juma, Tanzania Children in Prostitution: A Rapid Assessment, ILO-IPEC, Geneva (2001).

Lea Rouanet R., Gender Preferences in Africa: A Comparative Analysis of Fertility Choices. PSE, Working Papers No. 2014: 33. (2015).

Legal and Human Rights Centre, Tanzania Human Rights Report, 2012 (2013) LHRC 107.

Legal and Human Rights Centre, The Legal Process -- Can it Save Children from FGM? A Case of Three Maasai Girls in Morogoro, A Report on the Enforcement of FGM Law (2004) LHRC.

Levesque R.J., Sexual Use, Abuse and Exploitation of Children: Challenges in Implementing Children's Human Rights,” 60 BROOK. L. REV. (1994) 959- 973.

Lillie M, Cultural Forms of Human Trafficking in Africa (2013), Available at http://human trafficking search.net/wp/cultural-forms-of-human-trafficking-inafrica/ accessed on July 13, 2015.

Maki R., Ten Facts about Niger's 'Fifth Wives' or WAHAYU, Child Labor Coalition News of August 27, 2013, available at http://stopchildlabor.org/ Accessed on July 1, 2016.

Marcom V. Albinism in Tanzania: A Human Rights Issue, An Experience of Monitoring a White Black UniveritaDelis Studi Dipadova 2 (2013) available at http://www.academia.edu/9140081 /AlbinisminTanzania_accessed on April 27, 2015.

Mesaki S., Review of Witchcraft and the Law in Tanzania, International Journal of Sociology and Anthropology Vol. 1 (8) (2010) 132-138.

Mikhai S.L., Child marriage and Prostitution: Two Form of Sexual Exploitation? in Masika R. Gender Trafficking and Slavery, Oxfam (2002) 43-50.

Msuya S. E., Female Genital Cutting in Kilimanjaro, Tanzania: Changing Attitudes? Tropical medicine and International Health, Vol 7, No. 2 (2002). 159-165.

Mubangizi J. C., An African Perspective on Some Gender-Related Cultural Practices that Violate Human Rights and Perpetuate Women's Poverty. Journal of Social Sciences Interdisciplinary Reflection of Contemporary Society, 47(1): 68-78 (2016) available at http://krepublishers.com/02-Journals/JSS/JSS-47-0-00016-Web/JSS-47-1-000-16-Abst-PDF/JSS-47-1-068-16-1941-Mubangizi-J-C/JSS47-1-068-16-1941-Mubangizi-J-C-Tx[9].pdf.

Mulema J., Son Preference, Childbearing Behavior and Respondent Socio-Demographic Characteristics in Morogoro, Tanzania, ABC Journal of Advanced Research, Volume 3, No. 1 (2014) 9-13.

Mwambene L., Benign accommodation? Ukuthwala, 'forced marriage' and the South African Children's Act 1 AHRLJ (2011) 1-22.

Mwangeni A., Ankomah A. \& Powell R., Sex Preference and Contraceptive Behaviors Among Men in Mbeya Region, Journal of Family Planning and Reproductive Health Care, Vol 22 No. 2 (2001) 85-86. 
Namazie M., Racism, Cultural Relativism and Women's Rights, Speech at a panel discussion organized by the Action Committee on Women's Rights in Iran and Amnesty International's Women's Action Network, August 14, 2001, Toronto, Canada.

UN Human Rights, Niger: UN rights expert hails criminalization of slavery, but urges stronger law enforcement, UN Human Rights, The office of High Commissioner, November 21, 2014. Available http://www.ohchr.org/EN/NewsEvents/Pages/DisplayNews.aspx?NewsID=1533 0\&LangID=E Accessed on July 1, 2016.

Niger Code Pénal du Niger (2003) tel qu'amendé par la loi no. 2008-18.

Niger Combating Trafficking in Persons, enacted in 2010.

Niger is the Penal Code of 2003.

Niger Labor Code [LC], of 25 September 2012.

Odala V., How important is minimum age of marriage legislation to end child marriage in Africa? The African Child Policy Forum. June 11, 2013. Available at http://www.girlsnotbrides.org/how-important-is-minimum-age-of-marriagelegislation-to-end-child-marriage-in-africa/Accessed on June 28, 2016.

Osarenren L., Tradition at the Heart of Violence against Women and Girls in Africa, Inter-African Committee on Traditional Practices (IAC) Issue 351(2008) available at http://www.pambazuka.org/gender-minorities/tradition-heart-violenceagainst-women-and-girls-africa. Accessed on June 27, 2016.

Otnes C\& Tuncay-Zayer L., Gender, Culture, and Consumer Behavior, Routledge (2012).

Parrot A. \& Cumming N., Forsaken Females: The Global Brutalization of Women, Rowman and Littlefield Publishers, INC (2006) 47.

Pearson E., Study on trafficking in women in East Africa. A situational Analysis including. Current NGO and Governmental Activities as Well as Future Opportunities to Address Trafficking in Women and Girls in Ethiopia, Kenya, Tanzania, Uganda and Nigeria, Deutsche Gesellschaft für Technische Zusammenarbeit (GTZ), Ashburn, Germany (2003).

Richard R, Stephen G. and Steinner C., Perspectives on Africa: A Reader in Culture, History and Representation, Wiley-Blackwell (2010).

Ruby A and Benjamin N L., Anti-Trafficking Legislation in Sub-Saharan Africa: Analyzing the Role of Coercion and Parental Responsibility, Fourth Annual Interdisciplinary Conference on Human Trafficking, (20120. Paper 17. Available at http://digitalcommons.unl.edu/humtrafconf 4/17 Accessed on July 4, 2016.

Save the Children, Resource Centre: 'Tanzania, 2003 available at http://esourcecentre.savethechildren.se/countries/tanzania?f[0]=sm_field_publ ication_year\%3A2003. Accessed on August, 2015.

Schalkwyk J., Culture, Gender Equality and Development Cooperation, A paper prepared for the Canadian International Development Agency (CIDA) June 2000.

South Africa Criminal Law Sexual Offences Amendment Act, No. 41 of 2007.

South Africa Marriage Act, No. 25of 1961.

South Africa Promotion of Equality and Prevention of Unfair Discrimination (PEPUDA) Act, No 4 of 2000.

South African Children Rights No 38 of 2005.

Tanzania Anti-Trafficking in Persons Act, 2008.

Tanzania Law of Marriage Act, of 1971 CAP 29 [R.E. 2012].

Tanzania Local Customary Law [CAP 358 R.E. 2002]. 
Tanzania Women Lawyers Association (TAWLA), Position Paper on Gender Mainstreaming of the Constitution Review Process of Tanzania, Revised Edition, February 2013.

The African Charter on Human and Peoples' Rights of 1981.

The Commission for The Promotion and Protection of the Rights of Cultural, Religious and Linguistic Communities; Public Hearings and Research on Ukuthwala: Views and Perspectives Emerging from South African Communities Report (2011) Available http://www.gov.za/commission-promotion-and-protection-rightscultural-religious-and-linguistic-communities-hosts. Accessed on July 4, 2016.

The Convention on the Elimination of All Forms of Discrimination against Women (CEDAW) of 1979

The International Covenant on Civil and Political Rights (ICCPR) of 1966

The Protocol to Prevent, Suppress and Punish Trafficking in Persons, Especially Women and Children of 2000.

The Protocol to the African Charter on Human and Peoples' Rights on the Rights of Women in Africa of 2003

The United Nation Convention on the Elimination of All Forms of Discrimination against Women (CEDAW) of 1979.

The United Nations Convention against Transnational Organized Crime and the Protocols Thereto of 2000.

The Witchcraft Act of 1928 Cap.18 [R.E. 2002].

Thipanyane T., Human Trafficking: African Perspective, JURIST (2015) Academic Commentary, available at http://jurist.org/academic/2015/03/tselisothipanyane-trafficking-africa.php Accessed on October 12, 2015.

Truong T. Poverty, Gender and Human Trafficking in Sub-Saharan Africa: Rethinking Best Practices in Migration Management UNESCO (2006) 120.

Unites Nation Convention on the Rights of the Child of 1989.

UN Human Rights, Office of the High Commissioners Women's cultural rights: empowering and transformative, November 8, 2012. Available at http://www.ohchr.org/EN/NewsEvents/Pages/WomenCulturalRights.aspx

UN Protocol to Prevent Trafficking in Persons, United Nations of 2000 available athttp://www.uncjin.org. Accessed on 20 January 2016.

UN High Commissioner for Refugees (UNHCR). (2009). Guidance note on refugee claims relating to female genital mutilation, Para.1 Available at: http://www.refworld.org/pdfid/4a0c28492.pdf. Accessed on July 5, 2016.

UN Protocol to Prevent, Suppress and Punish Trafficking in Persons, Especially Women and Children of 2000.

UNFPA and The Guardian: Present the First Pan-African Award for Reporting on Female Genital Mutilation February 19, 2016 available at: http://www.unfpa.org/news/unfpa-and-guardian-present-first-pan-africanaward-reporting-female-genital-mutilation Accessed on July 4, 2016.

UNICEF, Female Genital Mutilation/Cutting: A statistical overview and exploration of the dynamics of change United Nations Children's Fund (UNICEF), July 2013.

United Nations Office on Drugs and Crime (UNODC), Addressing the root causes of trafficking, Toolkit to Combat Trafficking in Persons, Available at https://www. unodc.org/documents/human-trafficking/Toolkit-files/08-58296_tool_9-2.pdf accessed on July 14, 2015. 
United Nations Office on Drugs and Crime: Global Report on Trafficking in Persons 2014, UN 2004 available at https://www.unodc.org/documents/dataandnalysis/glotip/GLOTIP_2014_full_report.pdf Accessed on July12, 2016.

United Nations, Human Rights: International Instruments, Chart of Ratifications 5 (1995), U.N.Doc. St/Hr/5, U.N. Sales No. E.87.Xiv.2 (1995).

United States Department of State, Trafficking in Persons Report (2015) Available at www.state.gov/documents/organization/258881.pdf, Accessed on July 1, 2016.

Wambura S. \& Khaday P., Sexual Abuse Under Customary Practices, Stopping Shaming and Naming The Abuse of Power for Sexual Exploitation, Tanzania Women Judges Association (TAWJA) (2010).

Waritay \& Wilson, Working to end Female Genital Mutilation and Cutting in Tanzania the Role and Response of the Church, Tearfund, (2012).

Warner E., Behind the Wedding Veil: Child Marriage as a Form of Trafficking, Journal of Gender, Social Policy\& the Law. Vol 12 No. 2 (2011) 233-271.

White R., Invisible Women: Examining the Political, Economic, Cultural, and Social Factors that lead to Human Trafficking and Sex Slavery of Young Girls and Women, University of New Orleans Theses and Dissertations (2013)1708.

WHO, Female genital mutilation, (2013): Fact sheet No.241, Available at http://www.who.int/mediacentre/factsheets/fs241/en/

WHO. Female genital mutilation and obstetric outcome: WHO collaborative prospective study in six African countries. Lancet. 2006: http:// www.ncbi.nlm.nih.gov/pubmed/16753486.

ZakayoKatungo v Selemani Ningoli, District Court of Morogoro, Miscellaneous Criminal Cause No. 1 of 2002.

Zechenter E. M., In The Name of Culture: Cultural Relativism and the Abuse of the Individual, Journal of Anthropological Research, Vol. 53, No. 3, Universal Human Rights versus Cultural Relativity (1997) 319-347.

Zimmerman T.S. Integrating Gender and Culture in Parenting, Routledge (2002) 48. 